\title{
Role of the CD40 receptor/CD154 ligand dyad in the control of smooth muscle cells phenotype
}

\author{
Dissertation \\ zur Erlangung des Doktorgrades \\ der Mathematisch-Naturwissenschaftlichen Fakultäten \\ der Georg-August-Universität zu Göttingen
}

vorgelegt von

Milica Stojaković

aus Belgrad, Serbien und Montenegro

Göttingen 2003 
D7

Referent:

Prof. Dr. R. Hardeland

Korreferent:

Prof. Dr. W. Engel

Tag der mündlichen Prüfung: 


\section{Index}

Abbrevations III

1 Introduction 1

1.1 The CD40/CD154 receptor/ligand dyad 1

1.1.1 Structure of CD40 and CD154 1

1.1.2 CD40/CD154 expression pattern and chronic inflammation 1

1.1.3 CD40 signal transduction 2

1.2 Atherosclerosis - a chronic inflammatory disease 3

1.2.1 Cell-to-cell interactions in atherosclerosis 4

1.2.2 Role of smooth muscle cells in atherosclerosis 5

1.3 SMC plasticity 5

$\begin{array}{lll}1.4 & \text { Aims of the project } & 6\end{array}$

2. Materials and methods $\quad 7$

2.1 Cell biology methods $\quad 7$

2.1.1 Medium and substances for cell culture $\quad 7$

2.1.2 Culturing of human SMC from thymus veins (enzymatic digestion) 7

2.1.3 Cultivation of mouse myeloma cells 8

2.1.4 Cultivation of THP-1 cell line 8

2.1.5 Pre-stimulation of SMC with cytokines 8

2.1.6 Activation of CD40 receptor 9

2.1.7 Immunofluorescence analysis 10

2.1.8 Cell interaction assay 10

2.2 Molecular biology methods 11

2.2.1 Isolation of total RNA 11

2.2.2 Semi-quantitative RT-PCR 11

2.2.3 Sequencing of the PCR product 13

2.2.4 Decoy ODN technique 14

2.2.5 Western blot analysis 14

2.2.6 DNA microarray analysis 15

$\begin{array}{lll}2.2 .7 & \text { ELISA } & 16\end{array}$

$\begin{array}{lll}2.3 & \text { Statistical analysis } & 16\end{array}$ 
$\begin{array}{lll}3 & \text { Results } & 18\end{array}$

3.1 Characterisation of thymus vascular smooth muscle cells 18

3.2 Stimulation of SMC with IFN $\gamma /$ TNF $\alpha$ induces expression of CD40 18

3.3 CD40-induced expression of MCP-1 and MMP-3 in SMC 21

3.4 Signalling pathway involved in CD40 dependent MMP-3 activation 22

3.4.1 Increase in MMP-3 mRNA expression induced by CD154 stimulation is due to transcriptional activation $\quad 24$

3.4.2 CD154-induced MMP-3 mRNA expression does not require de novo protein synthesis 26

3.4.3 Effects of decoy ODN 27

3.5 Gene expression profile in SMC after CD40 ligation analysed by DNA $\begin{array}{ll}\text { microarray } & 28\end{array}$

3.5.1 Validation of the DNA microarray experiments 30

3.6 CD40-mediated SMC activation of monocytes 31

3.6.1 Effects of GM-CSF and IL-15 on CD40 and IL-8 expression 35

4 Discussion 36

4.1 The experimental model 36

4.2 CD40 expression in SMC 37

4.3 CD40 induced by IFN $\gamma$ and TNF $\alpha$ is functionally active 38

4.4 CD40-induced MMP-3 expression is dependent on Src-like tyrosine kinase and p38 mitogen-activated protein kinase 38

4.5 Characterization of CD40-mediated gene expression in SMC by DNA microarray analysis $\quad 41$

4.6 Functional significance of CD40 activation in SMC: activation of monocytes 42

4.7 A model of the role of SMC CD40 in atherosclerosis 43

5 Summary 46

References $\quad 48$

$\begin{array}{ll}\text { Acknowledgements } & 56\end{array}$ 


\section{Abbreviations}

Acc No

ActD

AP-1

APC

bp

BSA

CAMP

CCR

CDNA

C/EBP

$\mathrm{CHX}$

COX-2

D'MEM

DMSO

dNTP

dODN

ds

ECGS

ECM

EDTA

EF

ELISA

ERK

E-sel

JNK

FCS

GM-CSF

GRO

H89

HBSS

HEPES

HerbA

IAP-1 accession number

actinomycin D

activator protein-1

antigen-presenting cell

base pair

bovine serum albumin

cyclic adenosine mono-phosphate

CC chemokine receptor

complementary deoxynucleotide acid

CCAAT/enhancer-binding protein

cycloheximide

cyclooxygenase-2

Dulbecco's modified Eagle's medium

dimethyl sulphoxide

deoxynucleotide triphosphate

decoy oligodeoxynucleotide

double-stranded

endothelial cell growth supplement

extracellular matrix

ethylendinitrilo-N, N, N', N'-tetra-acetate

elongation factor

enzyme-linked immunosorbent assay

extracellular-signal-regulated kinase

E-selectin

c-Jun kinase

fetal calf serum

granulocyte-macrophage colony-stimulating factor

growth-regulated oncogene

$\mathrm{N}$-[2-((p-bromocinnamyl)amino)ethyl]-5-isoquinolinesulfonamide Hank's buffered salt solution

$\mathrm{N}$-2-Hydroxyethylpiperazine-N'-2-ethanesulfonic acid

herbimycin A

inhibitor of apoptosis protein-1 
ICAM-1 intercellular adhesion molecule-1

IFN- $\gamma \quad$ interferon gamma

IgM immunoglobulin M

IKK IKB kinase

IL interleukin

LDL low density lipoprotein

$\mathrm{mAb}$ monoclonal antibody

MAP kinase mitogen-activated protein kinase

MCP monocyte chemoattractant protein

$\mathrm{M}-\mathrm{CSF}$ macrophage colony-stimulating factor

MEK MAP kinase kinase

MIP macrophage inflammatory protein

MHC II major histocompatibility complex class II

MMP matrix metalloproteinase

mRNA messenger RNA

MT-MMP membrane-type matrix metalloproteinase

NF-kB nuclear factor kappa B

NIK NF- $\kappa$ B-inducing kinase

PBS phosphate-buffered saline

PD 98059 2'-amino-3'-methoxyflavone

PDE IV phosphodiesterase IV

PECAM-1 platelet endothelial cell adhesion molecule-1

$\mathrm{PI}-3 \mathrm{~K} \quad$ phosphatidylinositol-3 kinase

PKA protein kinase $\mathrm{A}$

RANTES regulated upon activation, normal T-cell-expressed and secreted

RNase ribonuclease

RO 31-8220 3-[1-[3-(amidinothio)propyl-1H-indol-3-yl]-3-(1-methyl-1H-indol-3yl) maleimide; bisindolylmaleimide IX, methanesulfonate

ROCK Rho kinase

RPL ribosomal protein large unit

RT room temperature

RT-PCR reverse transcription polymerase chain reaction SAPK stress-activated protein kinase 4-(4-fluorophenyl)-2-(4-hydroxyphenyl)-5-(4-pyridyl)1H-imidazole 
SD

SEM

SMC

sS

STAT

TF

TNF- $\alpha$

TNFAIP

TRAF

Tris

$U$

UPA

UPAR

VCAM-1

VEGF

Y27632 standard deviation

standard error of the mean

smooth muscle cell

single-stranded

signal transducer and activator of transcription

transcription factor

tumor necrosis factor- $\alpha$

tumor necrosis factor alpha-induced protein

TNF receptor associated factor

Tris-(hydroxymethyl)-aminomethan

unit

urokinase plasminogen activator

urokinase plasminogen activator receptor

vascular cell adhesion molecule-1

vascular endothelial growth factor

(+)-(R)-trans-4-(1-aminoethyl)-N-(4-pyridyl)

cyclohexanecarboxamide 


\section{Introduction}

\subsection{The CD40/CD154 receptor/ligand dyad}

\subsubsection{Structure of CD40 and CD154}

CD40 is a cell surface receptor that belongs to the tumor necrosis factor receptor (TNF-R) family. The human CD40 gene is mapped to chromosome 20 (q11-q13.2) and consists of 9 exons. The fully maturated protein has 255 amino acids and consists of a 22 amino acid trans-membrane domain connecting a 171 amino acid extracellular domain and a 62 amino acid intracellular domain. CD40 is characterized by a repetitive amino acid sequence pattern of four cystein-enriched sub-domains, typically consisting of six cystein residues forming three disulfide bridges (Stamenkovic et al., 1989).

CD154 is the only known specific ligand for CD40. It belongs to the TNF family of proteins. The CD154 gene is mapped to chromosome X (q26.3-q27.1) and consists of 5 exons. The first exon encodes the intracellular, transmembrane and a small part of the extracellular domain, while exons II-V encode the rest of the extracellular domain. The molecular mass of its membrane-bound form is $39 \mathrm{kDa}$. However, three biologically active, soluble fragments of 31,18 , and $14 \mathrm{kDa}$ protein derived from proteolytic cleavage of the membrane-bound form have been characterized (Graf et al, 1995; Ludewig et al., 1996; Wykes et al., 1998).

\subsubsection{CD40/CD154 expression pattern and chronic inflammation}

CD40 and CD154 were first discovered on the surface of B-cells and T-cells, respectively (Paulie et al., 1984). The crucial role of CD154/CD40 interaction in Tcell-dependent B-cell activation and differentiation can best be understood when the consequences of certain genetic polymorphisms in the human CD154 gene are analysed. Several point mutations in the CD154 gene are associated with the socalled 'family X-linked hyperimmunoglobulin M syndrome' (Allen et al., 1993). This disease not only is characterized by elevated concentrations of serum $\operatorname{lgM}$ and decreased amounts of all other immunoglobulin isotypes, but also by a decreased sensitivity to activation and proliferation of B-cells. Consequently, patients with this syndrome suffer from chronic infections of the upper respiratory tract as well as a 
number of opportunistic or viral infections (Durandy et al., 1993). Moreover, Th1dependent inflammatory reactions are weakened indicating even more important functions of CD40/CD154 interactions in the regulation of the cellular immune response (Grewal and Flavell, 1998).

Apart from the importance of CD154/CD40 co-stimulation for the mounting of an appropriate immune response, more recent studies associated this co-stimulatory pathway with the exaggerated reaction of the immune response in various chronic inflammatory and autoimmune diseases. Moreover, CD154 is also expressed by nonimmune cells such as activated platelets (Henn et al., 1998), while CD40 is expressed in epithelial cells, fibroblasts and endothelial cells (Alderson et al., 1993, Yellin et al., 1995, Karmann et al, 1995), as well as in SMC under pro-inflammatory conditions (Krzesz et al., 1999). This broader distribution of CD40 and CD154 also points to the likely involvement of this receptor/ligand dyad in chronic inflammatory diseases such as asthma, rheumatoid arthritis, psoriasis, type I diabetes and multiple sclerosis, to name a few, but also in atherosclerosis (Schonbeck and Libby, 2001).

\subsubsection{CD40 signal transduction}

CD154 is capable of forming a trimeric structure which, as a consequence, induces trimerization of the CD40 receptor protein (Peitsch et. al, 1993). This trimerization is necessary for optimal CD40 signalling (Pullen et. al, 1999). Although CD40 has no kinase domain, CD40 ligation activates several second messenger systems through (i) activation of separate kinases/phosphatases, and/or (ii) recruitment and activation of several signalling proteins.

Ligation of CD40 on activated B-cells thus results in enhanced tyrosine phosphorylation of four distinct phosphoproteins and induces a rapid increase in the production of inositol 1,4,5-triphosphate (Uckun et al., 1991). Later reports described a wortmannin-sensitive kinase activity, implicating involvement of phosphatidylinositol-3-kinase (PI-3K) in CD40 signalling (Aagaard-Tillery et al., 1996). Also, the Src-family tyrosine kinases syk, lyn, and fyk have been associated with CD40 signalling (Tan et al., 2000). Finally, signalling pathways downstream from $\mathrm{PI}-3 / \mathrm{PI}-3-\mathrm{K}$ and syk/lyn/fyk result in the activation of various transcription factors,

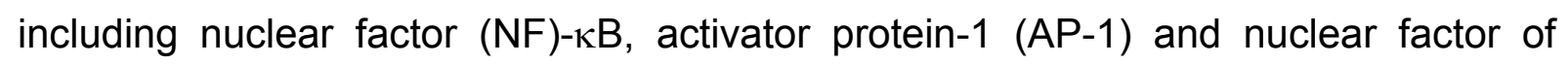
activated T cells (NFAT) (Karmann et al., 1996). 
The TNF-R family-associated factors (TRAFs) consist of six known members that share homology in the C-terminal domain. This domain is required for multimerization and binding of the TRAFs to members of the TNF-R family. TRAF3 has been identified as the first protein associated with the cytoplasmic domain of CD40. In addition to TRAF3, TRAF1, TRAF2, TRAF5 and TRAF6 have been associated with CD40 signalling (Ishida et al., 1996). Overexpression of TRAF2, TRAF5, and TRAF6 in B-cells activates stress-activated protein kinases (SAPK) and NF- $\mathrm{B}$. In addition, CD40/TRAF6 interaction leads to activation of the extracellular signal-regulated kinases (ERK) 1 and 2 as well as p38 mitogen-activated protein kinase (MAPK). This,

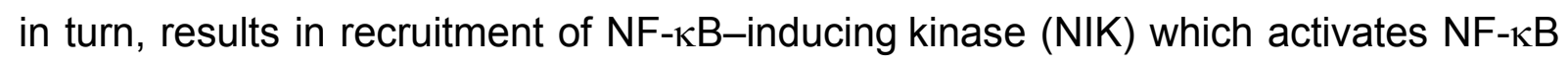
through IKB-kinase I/II (IKK-I/IKK-II) (Brady et al., 2000). Moreover, TRAF2 and TRAF6 can activate the JNK signalling pathway.

Besides TRAFs, members of the family of signal transducers and activators of trancription (STATs) have been implicated in CD40 signalling (Karras et al., 1997). STAT proteins form homo- and hetero-dimers after phosphorylation, translocate to the nucleus, and bind specific DNA elements, enabling them to directly induce gene expression (Darnell et al., 1994).

Thus, CD40 signalling seems to be rather complex. On the other hand, not all CD40expressing cells execute all the signal transduction pathways CD40 is principally capable to activate, making it rather difficult to sort out the signalling mechanism in a given cell type that mediates the physiological/pathophysiological response to CD40 activation.

\subsection{Atherosclerosis - a chronic inflammatory disease}

In principle, atherosclerosis must be considered as a chronic inflammatory disease of the vessel wall that is restricted to arteries and arterioles (Ross, 1993). Because high plasma concentrations of cholesterol, in particular low density lipoprotein (LDL) cholesterol, are among the principal risk factors for atherosclerosis, the process of atherogenesis has been considered by many to consist largely of the accumulation of lipids within the artery wall. However, despite changes in life style and the use of new pharmacological approaches to lower plasma cholesterol concentrations (Shepherd, 1995), atherosclerosis and its consequences (myocardial infarction, heart failure and stroke) continues to be the leading cause of death in industrialized nations. 
Atherosclerotic lesions represent a series of cellular responses that can be described as an inflammatory disease. From the start of the disease, inflammatory cells and mediators are major components of the atherosclerotic plaque. Fatty streaks, the socalled early lesions, already contain significant numbers of activated macrophages and T-cells (Emeson et al., 1988). In the course of lesion progression, the number of pro-inflammatory cells in the vessel wall increases even further (Ross, 1999).

\subsubsection{Cell-to-cell interactions in atherosclerosis}

In atherosclerosis a wide variety of cell-to-cell interactions are important, including leukocyte-endothelial cell, leukocyte-leukocyte, leukocyte-vascular smooth muscle cell, and leukocyte-interstitial cell interactions. The proteins mediating these interactions are adhesion molecules that belong to four major families: (1) selectins, (2) selectin ligands, (3) integrins, and (4) members of the immunoglobulin superfamily (Springer, 1994). A major function of these adhesion molecules is to promote leukocyte recruitment from the circulating blood into the tissue through a series of events, including leukocyte rolling along the endothelial cell surface, firm adhesion and activation and, finally, extravasation into the vessel wall.

The normal endothelium does not in general support rolling and binding of leukocytes. When the endothelial monolyer becomes inflamed, it express selectins and selectin ligands that are mediating leukocyte rolling (Eriksson et al., 2000). Also, activated endothelium express adhesion molecules that bind cognate ligands on leukocytes. In particular, vascular cell adhesion molecule-1 (VCAM-1) binds precisely the types of leukocytes found in early atheroma, the monocyte and T-cells (Li et al., 1993). Once adherent to the endothelium, the leukocytes penetrate into the intima. Recent research has identified candidate chemoattractant molecules responsible for this transmigration. For example, monocyte chemoattractant protein-1 (MCP-1) appears responsible for the direct migration of monocytes into the intima at sites of lesion formation (Boring et al., 1998). In addition to MCP-1, macrophage colony stimulating factor (M-CSF) contributes to the differentiation of the blood monocytes into the macrophage foam cells (Smith et al., 1995). Besides, chemokine binding also increases the cellular production of other cytokines and growth factors further amplifying the inflammatory response. 


\subsubsection{Role of smooth muscle cells in atherosclerosis}

In the initial phase of atherosclerosis, contact between endothelial cells and circulating leukocytes plays a pivotal role. Circulating leukocytes adhere to endothelial cells, migrate through them and enter the vessel wall. This process allows vascular smooth muscle cells (SMC) to come into contact with the infiltrating leukocytes. One hallmark of lesion progression in humans is the focal accumulation of medial SMC within the neointima. In early atherosclerosis, SMC may contribute to lesion formation through the production of pro-inflammatory mediators such as MCP1 and VCAM-1, and through the synthesis of matrix molecules required for the retention of lipoproteins (Schwartz et al., 1995). However, in later phases of the disease, SMC may also be important in maintaining the stability of the plaque through formation of a firm fibrous cap. Indeed, in lipid-laden lesions in which the fibrous cap is thin or weakened, there is evidence of SMC apoptosis, especially at the 'shoulder' region, that is associated with inflammation (Fuster et al., 1994). In addition, the local inflammatory milieu can induce expression of collagenase and inhibit expression of proteolytic inhibitors, thus rendering the fibrous cap susceptible to rupture (Libby et al., 2002, Ross et al., 1973). The resulting acute thrombosis may lead to complete vessel occlusion and infarction.

In this contest, it is of particular interest that SMC expressing CD40 contribute to the development of atherosclerosis via CD154-CD40 interaction. CD40 activation on SMC leads to SMC activation characterized by the expression of matrix metalloproteinases (MMPs), interleukin-1 beta (IL-1ß) and tissue factor (Horton et al., 2001; Schonbeck et al., 1997; Schonbeck et al., 2000).

\subsection{SMC plasticity}

Intimal SMC associated with vascular disease are phenotypically distinct from their medial counterparts (Mosse et al., 1985; Campbell et al., 1985). Intimal SMC resemble immature, dedifferentiated SMC that have low levels of contractile proteins but express large amounts of proteins contributing to progression of the atherosclerotic plaque and its degree of inflammation that makes it prone to rupture. Under normal physiological conditions, SMC plasticity is very important. The contractile phenotype is essential for hemodynamic stability. After injury, SMC are able to dedifferentiate, proliferate, produce an appropriate extracellular matrix and, 
via this way contribute to repairing the injured vessel wall. Interestingly only two morphologically distinct SMC cell types can be isolated from the media of healthy human arteries (Li et al., 2001). In contrast, several different SMC or myofibroblastlike cells can be characterized in the neointima of atherosclerotic lesions. This SMC phenotype alteration in the course of atherosclerosis is a consequence of prolonged exposure to inappropriate mechanical stress, cell-matrix and cell-to-cell interactions.

\subsection{Aims of the project}

The hypothesis underlying this thesis is that CD40 signalling in SMC may play an important role in the development of atherosclerosis. However, expression and possible effects of CD40 in this cell type, especially with respect to the situation in humans are only poorly understood. Therefore, the first aim of the thesis was to characterize CD40 expression in human cultured SMC under basal and under proinflammatory conditions. After having established near optimal conditions for CD40 expression in these cells, a detailed analysis of the signalling mechanisms underlying CD40-induced gene expression and profiling of CD154-induced gene products were performed in parallel. Finally, the functional consequences of the changes in SMC phenotype were elucidated, paying special attention to the putative interaction between leukocytes and SMC in the vessel wall during atherogenesis. 


\section{Materials and methods}

\subsection{Cell biology methods}

\subsubsection{Medium and substances for cell culture}

$\begin{array}{lll}\text { SMC growth medium 2 } & \text { Promocell } & \text { Karlsruhe } \\ \text { DMEM } & \text { Life Technologies } & \text { Karlsruhe } \\ \text { M199 } & \text { Life Technologies } & \text { Karlsruhe } \\ \text { RPMI } 1640 & \text { Life Technologies } & \text { Karlsruhe } \\ \text { HBSS } & \text { Life Technologies } & \text { Karlsruhe } \\ 0.05 \% \text { Trypsin/0.2\% EDTA } & \text { Life Technologies } & \text { Karlsruhe } \\ \text { HEPES } & \text { Roth } & \text { Karlsruhe } \\ \text { Nystatin } & \text { Life Technologies } & \text { Karlsruhe } \\ \text { Penisillin } & \text { Life Technologies } & \text { Karlsruhe } \\ \text { Streptomycin } & \text { Life Technologies } & \text { Karlsruhe } \\ \text { FCS } & \text { Life Technologies } & \text { Karlsruhe } \\ \text { Heparin } & \text { Sigma-Aldrich } & \text { Deisenhofen } \\ \text { Gelatine } & \text { Sigma-Aldrich } & \text { Deisenhofen } \\ 0.15 \% \text { Collagenase } & \text { Sigma-Aldrich } & \text { Deisenhofen } \\ \text { Ficoll-Paque } ® & \text { Amersham } & \text { Freiburg }\end{array}$

\subsubsection{Culturing of human SMC from thymus veins (enzymatic digestion)}

Smooth muscle cells were obtained from the thymus of young children (up to 2 years old) undergoing heart surgery. All patients had given their written consent prior to the surgical procedure. The consent was also approved by the Local Ethical Committee. The small veins were excised from the organ, freed of adjacent fat and connective tissue, and transferred to a $60 \mathrm{~mm}$ petri dish containing $250 \mu \mathrm{l}$ collagenase solution and $1.4 \mathrm{ml}$ DMEM medium with $5 \%$ FCS. The petry dishes were placed in an incubator at $37^{\circ} \mathrm{C}$ and $5 \% \mathrm{CO}_{2}$ to allow digestion of the extracellular matrix overnight (14-16 h). Thereafter the isolated cells were centrifuged for $5 \mathrm{~min}$ at $1000 \mathrm{rpm}$ and ambient temperature, the pellet was resuspended in 2-3 $\mathrm{ml}$ of smooth muscle cell growth medium and allowed to adhere to petri dish previously coated with $2 \%$ gelatine. The medium was changed every 2 days thereafter. 
After reaching 90-100\% confluence (approximately after 5-6 days) cells were passaged by using trypsin/ EDTA $\left(5 \mathrm{~min}, 37^{\circ} \mathrm{C}, 5 \% \mathrm{CO}_{2}\right.$ ). For the experiments described, cells of passage 3 to 4 were used throughout.

At the light microscopy level, their identity with SMC was confirmed by the typical hilland-valley growth pattern and in addition, by positive immunostaining for smooth muscle cell $\alpha$-actin, and negative immunostaining for von Willebrandt factor (endothelial cells).

\subsubsection{Cultivation of mouse myeloma cells}

The mouse myeloma cell line P3xTB.A7 stably expressing human CD154 and the non-transfected P3x63Ag8.653 control cells were kind gifts of Prof. R. Kroczek (Robert-Koch-Institute, Berlin). They were cultured in RPMI 1640 medium with 10\% FCS under $5 \% \quad \mathrm{CO}_{2}$ at $37^{\circ} \mathrm{C}$. Every three months, cells were selected with gentamycin (G-418 sulphate, Gibco-BRL, Life Technologies, Karlsruhe) to maintain expression of the transgene.

\subsubsection{Cultivation of THP-1 cell line}

The human premonocytic cell line THP-1 was purchased from the American Type Culture Collection (Rockville, MD). The cells were cultured in RPMI 1640 medium with $10 \%$ FCS under $5 \% \mathrm{CO}_{2}$ at $37^{\circ} \mathrm{C}$, at a density between $2 \times 10^{5}$ and $1 \times 10^{6}$ cells/ml.

\subsubsection{Pre-stimulation of SMC with cytokines}

The cytokines IFN $\gamma(1000 \mathrm{U} / \mathrm{ml})$ and TNF $\alpha(100 \mathrm{U} / \mathrm{ml})$ were used to stimulate CD40 receptor expression in the cultured smooth muscle cells. Incubation times varied from 6-24 $\mathrm{h}\left(37^{\circ} \mathrm{C}, 5 \% \mathrm{CO}_{2}\right)$. After this time, the conditioned medium was replaced with fresh medium and cells left for another 12-h period to allow for maximum CD40 protein expression on the surface of the smooth muscle cells. 


\subsubsection{Activation of CD40 receptor}

The cytokine pre-stimulated SMC were co-incubated with the P3xTB.A7 cells (expressing human CD154), P3x63Ag8.653 control cells or with the P3xTB.A7 cells in the presence of a monoclonal anti-CD154 antibody (Pharmingen, Germany, 40 $\mu \mathrm{g} / \mathrm{mL})$ for $12 \mathrm{~h}$ in the incubator $\left(37^{\circ} \mathrm{C}, 5 \% \mathrm{CO}_{2}\right)$.

Table 1. Substances used as signal transduction inhibitors

\begin{tabular}{|c|c|c|c|c|}
\hline Substance & Final concentration & Effect & Source & Diluted in \\
\hline Actinomycin D & $1 \mu \mathrm{M}$ & Transcription inhibitor & Sigma & DMSO \\
\hline Cycloheximide & $1 \mu \mathrm{g} / \mathrm{mL}$ & Translation inhibitor & Sigma & DMSO \\
\hline Forskolin & $10 \mu \mathrm{M}$ & $\begin{array}{l}\text { Activator of adenylat } \\
\text { cyclase }\end{array}$ & Calbiochem & DMSO \\
\hline Herbimycin A & $1 \mu \mathrm{M}$ & $\begin{array}{l}\text { Tyrosine kinase } \\
\text { inhibitor with Src } \\
\text { selectivity }\end{array}$ & Alexis & Water \\
\hline H89 & $1 \mu \mathrm{M}$ & PKA inhibitor & Alexis & Water \\
\hline PD98059 & $50 \mu \mathrm{M}$ & MEK-1/2 inhibitor & Calbiochem & DMSO \\
\hline Rapamycin & $10 \mathrm{nM}$ & P70 S6 kinase inhibitor & Calbiochem & DMSO \\
\hline RO31-8220 & $1 \mu \mathrm{M}$ & PKC inhibitor & Calbiochem & DMSO \\
\hline Rolipram & $12.5 \mu \mathrm{M}$ & PDE IV inhibitor & Calbiochem & DMSO \\
\hline SB202190 & $10 \mu \mathrm{M}$ & $\begin{array}{l}\text { p38 MAP kinase } \\
\text { inhibitor }\end{array}$ & Calbiochem & DMSO \\
\hline SP600125 & $20 \mu \mathrm{M}$ & JNK inhibitor & Biomol & DMSO \\
\hline Y27632 & $10 \mu \mathrm{M}$ & Rho kinase inhibitor & Calbiochem & Water \\
\hline Wortmannin & $100 \mathrm{nM}$ & PI3K inhibitor & Sigma & Ethanol \\
\hline
\end{tabular}

To interfere with CD40 signalling to the nucleus in stimulated SMC, the drugs listed in Table 1 were employed. Typically they were pre-incubated with the cultured SMC for $1 \mathrm{~h}$, before addition of P3XTB.A7 cells and left in the medium throughout the remaining period of the experiment. If required, an appropriate solvent control (DMSO, 0.05\% v/v) was analysed, too. 


\subsubsection{Immunofluorescence analysis}

$\alpha$-Actin staining

SMC were washed twice in PBS [140 mM NaCl, 2,7 mM KCL, 9 mM Na $2 \mathrm{HPO}_{4}, 1,5$ $\mathrm{mM} \mathrm{KH} \mathrm{KO}_{4}(\mathrm{pH} \mathrm{7,4)]} \mathrm{and} \mathrm{fixed} \mathrm{in} \mathrm{3.3 \%} \mathrm{p-formaldehyde} \mathrm{(30} \mathrm{min,} \mathrm{at} \mathrm{ambient}$ temperature followed by $30 \mathrm{~min}$, at $4^{\circ} \mathrm{C}$ ). To inactivate aldehyde groups cells were treated with $50 \mathrm{mM}$ ammoniumchloride (30 $\mathrm{min}$ ). Thereafter, cells were subsequently blocked with blocking solution II (0.2\% TritonX in blocking solution I, $5 \mathrm{~min})$, and blocking solution I (0.2\% fish skin gelatine in PBS, $10 \mathrm{~min})$, followed by incubation with the mouse anti-human $\alpha$-actin antibody (Sigma) for $30 \mathrm{~min}$. To visualise the bound primary antibody, goat anti-mouse IgG conjugated with Alexa Fluor 488 (R\&D systems, Germany) was applied at a dilution of 1:100 (30 min, in the dark). Glass slides were prepared using $15 \mu$ of $50 \%$ glycerin and analysed using an inverted epifluorescence microscope (Axiovert S 100; Zeiss, Germany).

\section{Staining for VCAM-1 expression}

SMC were washed twice with Hepes-Tyrode and incubated with a monoclonal mouse anti-human VCAM-1 antibody (R\&D systems, Germany) at a dilution of 1:100 (60 min, ambient temperature). After 3 washes cells were fixed with $3.3 \% p$ formaldehyde (30 $\mathrm{min}$ ) followed by incubation with amoniumchloride (10 min). After that $0,1 \%$ saponin (diluted in Hepes-Tyrode buffer) was added to avoid unspecific binding (10 $\mathrm{min}$ ) followed by a 30-min incubation with a goat anti-mouse IgG conjugated with Alexa Fluor 488 at a dilution of 1:100 in the dark. Glass slides were prepared as described above.

\subsubsection{Cell interaction assay}

For cell interaction studies, cell culture inserts containing PET membranes (BD Falcon, Heidelberg, Germany) with a pore size of $8.0 \mu \mathrm{m}$ and a density of $1 \times 10^{5}$ pores $/ \mathrm{cm}^{2}$ were fitted into 12-well plates (Techno Plastic Products AG, Trasadingen, Switzerland). SMC were allowed to grow on the PET membranes until reaching confluence. Thereafter, SMC were pre-stimulated with IFN $\gamma$ plus TNF $\alpha$ for $24 \mathrm{~h}$, medium was changed for $12 \mathrm{~h}$ and then the SMC were co-incubated with the P3xTB.A7 or P3x63Ag8.653 myeloma cells $\left(1 \times 10^{6}\right.$ cells $\left./ \mathrm{mL}\right)$ for $12 \mathrm{~h}$. Co-incubations 
were terminated by removing the supernatant, followed by a thorough washing of the SMC layer with medium M199 to remove the myeloma cells. For subsequent migration studies, $1 \times 10^{6} / \mathrm{mL}$ THP-1 cells were presented to the SMC side of the membrane in the presence of $100 \mathrm{ng} / \mathrm{mL}$ recombinant MCP-1 (R\&D Systems, Wiesbaden, Germany) in lower or sub-SMC compartment (trans) and allowed to migrate for $12 \mathrm{~h}$. In some experiments, SMC were pre-incubated for 90 min with the CD154-neutralizing antibody before addition of the THP-1 monocytes. THP-1 cells that migrated through the SMC layer were quantified by counting under the light microscope, followed by RNA isolation and RT-PCR analysis or IL-1ß protein determination.

\subsection{Molecular biology methods}

\subsubsection{Isolation of total RNA}

Total RNA was extracted from cultured smooth muscle cells, THP-1 cells or myeloma cells by using the RNeasy kit $^{\circledR}$ (Qiagen, Germany) according to the manufacturer's instructions. Briefly, cells cultured either in 6-well plates or 12-well plates (TPP, Germany) were washed twice with PBS before being disrupted by the addition of RLT buffer and homogenized by 5 times passing through a 20-gauge needle. Then, $600 \mu \mathrm{l} 70 \%$ ethanol were added and mixed immediately by pipetting. The mixture (approximately $700 \mu \mathrm{l}$ ) was applied twice to an RNeasy ${ }^{\circledR}$ mini column to bind the RNA by centrifugation at $13,000 \mathrm{rpm}$ for $15 \mathrm{~s}$. The column was washed once with $700 \mu$ buffer RW1, and twice with $500 \mu$ l buffer RPE. After the last washing step, an additional centrifugation at $13,000 \mathrm{rpm}$ for $1 \mathrm{~min}$ was performed to dry the membrane. RNA was eluted into $40 \mu \mathrm{l}$ RNase-free water and stored at $-70^{\circ} \mathrm{C}$.

\subsubsection{Semi-quantitative RT-PCR}

For each sample, $1 \mu \mathrm{g}$ RNA was mixed with $1 \mu \mathrm{l}$ oligo-dT(15) $(500 \mathrm{ng} / \mu \mathrm{l})$ in a total volume of $14 \mu \mathrm{l}$ and denatured by incubation at $70^{\circ} \mathrm{C}$ for $10 \mathrm{~min}$. After brief centrifugation, $6 \mu \mathrm{l}$ cDNA-Synthesis-Mix [50 mM Tris/HCl (pH 8.3), 75 mM KCl, 3 mM $\mathrm{MgCl}_{2}, 10 \mathrm{mM}$ DTT, $2.5 \mathrm{mM}$ dNTP and $200 \mathrm{U}$ MMLV reverse transcriptase] was added and cDNA synthesis continued for $50 \mathrm{~min}$ in a water bath at $42^{\circ} \mathrm{C}$. The 
reaction was stopped by heating to $70^{\circ} \mathrm{C}$ for $10 \mathrm{~min}$. Each cDNA sample was diluted with $180 \mu \mathrm{H}_{2} \mathrm{O}$ and stored at $-20^{\circ} \mathrm{C}$.

Semi-quantitative PCR analysis was performed by normalizing to the relative amount of cDNA of a house-keeping gene. For this purpose, the ribosomal protein L32 (RPL32) was chosen as internal standard. The reagents for PCR amplification were premixed to ensure identical conditions in each reaction $[20 \mathrm{mM}$ Tris/ $\mathrm{HCl}(\mathrm{pH} 8.4)$, $1.5 \mathrm{mM} \mathrm{MgCl}$, $0.2 \mathrm{mM}$ dNTP, 20 pmol primers (for both forward and reverse primers) and $1 \mathrm{U}$ Taq DNA polymerase, in a total volume of $50 \mu \mathrm{l}$. The PCR reaction was performed in a model thermocycler (Eppendorf, Germany) programmed as follows:

Pre-denaturation: $\quad 2 \min$ at $94^{\circ} \mathrm{C}$

Denaturation: $\quad 30 \mathrm{~s}$ at $94^{\circ} \mathrm{C}$

Annealing: $\quad 30 \mathrm{~s}$ at the temperatures shown in Table 2

Extension: $\quad 30 \mathrm{~s}-1 \mathrm{~min}$ (depending on the fragment size) at $72^{\circ} \mathrm{C}$

Cycles: $\quad$ primer-specific number as shown in Table 2

Final extension: $\quad 5 \min$ at $72^{\circ} \mathrm{C}$

After the amplification, PCR products were separated on $1.7 \%$ agarose gels with ethidium bromide staining. The density of the detected bands was determined by using PhotoFinish ${ }^{\circledR}$ imaging system (WordStar Atlanta Technology Center, USA) and One-Dscan $^{\circledR}$ (software, Scananlytics, Billerica, USA). These results permitted adjustments for the volume of cDNA administered in order to obtain (in a PCR reaction of 20 cycles) the identical quantity of the product for the housekeeping gene (RPL-32). With that amount of cDNA fixed, the PCR reactions were performed with specific primers for the genes of interest. 
Table 2. RT-PCR primers employed

\begin{tabular}{|c|c|c|c|c|c|}
\hline $\begin{array}{l}\text { gene } \\
\text { product }\end{array}$ & $\begin{array}{l}\text { GeneBank } \\
\text { accession } \\
\text { position }\end{array}$ & $\begin{array}{l}\text { Length } \\
\text { (bp) }\end{array}$ & $\begin{array}{l}\text { No. of } \\
\text { cycles }\end{array}$ & $\begin{array}{l}\text { Annealing } \\
\text { temperature }\end{array}$ & Primer (for/rev) \\
\hline CCR7 & $\begin{array}{l}\text { XM_049959 } \\
\text { 329-794 }\end{array}$ & 465 & 33 & $60^{\circ} \mathrm{C}$ & $\begin{array}{l}\text { TCAAGACCATGACCGATACC } \\
\text { AGGTAACAGAAGCTCATGGC }\end{array}$ \\
\hline CD154 & $\begin{array}{l}X 96710 \\
231-559\end{array}$ & 328 & 33 & $55^{\circ} \mathrm{C}$ & $\begin{array}{l}\text { GAGATGCAACACAGGAGAAAGATCC } \\
\text { TGGAACAGAAGGTGACTTGGGC }\end{array}$ \\
\hline CD40 & $\begin{array}{l}\text { NM001250 } \\
202-582\end{array}$ & 380 & $25-27$ & $60^{\circ} \mathrm{C}$ & $\begin{array}{l}\text { CAGAGTTCACTGAAACGGAATGCC } \\
\text { TGCCTGCCTGTTGCACAACC }\end{array}$ \\
\hline E-sel & $\begin{array}{l}\text { M30640 } \\
2824-3283\end{array}$ & 459 & $31-33$ & $60^{\circ} \mathrm{C}$ & $\begin{array}{l}\text { AGCAAGGCATGATGTTAACC } \\
\text { GCATTCCTCTCTTCCAGAGC }\end{array}$ \\
\hline GRO- $\gamma$ & $\begin{array}{l}M 36821 \\
175-400\end{array}$ & 225 & 27 & $60^{\circ} \mathrm{C}$ & $\begin{array}{l}\text { GAGCGTCCGTGGTCACTGAA } \\
\text { TGTCAGTTGGTGCTCCCCTT }\end{array}$ \\
\hline IL-1 $\beta$ & $\begin{array}{l}\text { M54933 } \\
226-555\end{array}$ & 329 & $29-31$ & $59^{\circ} \mathrm{C}$ & $\begin{array}{l}\text { GGCATCCAGCTACGAATCTCCG } \\
\text { CACTTGTTGCTCCATATCCTGTCCC }\end{array}$ \\
\hline IL-8 & $\begin{array}{l}\text { XM_170504 } \\
149-655\end{array}$ & 506 & $27-29$ & $58^{\circ} \mathrm{C}$ & $\begin{array}{l}\text { GCCAAGGAGTGCTAAAGAAC } \\
\text { CTCCCGTGCAATATCTAGGA }\end{array}$ \\
\hline IL-15 receptor $\alpha$ & $\begin{array}{l}\text { NM_002189 } \\
\text { 313-774 }\end{array}$ & 461 & 27 & $62^{\circ} \mathrm{C}$ & $\begin{array}{l}\text { GAACAAGGCCACGAATGTCG } \\
\text { CTTGACTTGAGGTAGCATGC }\end{array}$ \\
\hline IL-23p19 & $\begin{array}{l}\text { NM_016584.1 } \\
260-719\end{array}$ & 459 & $35-36$ & $61^{\circ} \mathrm{C}$ & $\begin{array}{l}\text { CACAGAAGCTCTGCACACTGGC } \\
\text { TAGGGACTCAGGGTTGCTGCTC }\end{array}$ \\
\hline MCP-1 & $\begin{array}{l}X 14768 \\
46-376\end{array}$ & 330 & $22-24$ & $63^{\circ} \mathrm{C}$ & $\begin{array}{l}\text { GCGGATCCCCTCCAGCATGAAAGTCTCT } \\
\text { ACGAATTCTTCTTGGGTTGTGGAGTGAG }\end{array}$ \\
\hline MIP-3 $\alpha$ & $\begin{array}{l}\text { U64197 } \\
51-313\end{array}$ & 262 & $31-33$ & $60^{\circ} \mathrm{C}$ & $\begin{array}{l}\text { TACCAAGAGTTTGCTCCTGG } \\
\text { TTTTACTGAGGAGACGCAC }\end{array}$ \\
\hline MMP-3 & $\begin{array}{l}\text { NM_002422.2 } \\
790-1083\end{array}$ & 293 & $30-33$ & $60^{\circ} \mathrm{C}$ & $\begin{array}{l}\text { CTCACAGACCTGACTCGGTT } \\
\text { CACGCCTGAAGGAAGAGATG }\end{array}$ \\
\hline RPL-32 & $\begin{array}{l}\times 03342 \\
91-459\end{array}$ & 368 & $18-22$ & $60^{\circ} \mathrm{C}$ & $\begin{array}{l}\text { GTTCATCCGGCACCAGTCAG } \\
\text { ACGTGCACATGAGCTGCCTAC }\end{array}$ \\
\hline VCAM-1 & $\begin{array}{l}X 53051 \\
729-1252\end{array}$ & 523 & $22-24$ & $63^{\circ} \mathrm{C}$ & $\begin{array}{l}\text { CATGACCTGTTCCAGCGAGG } \\
\text { CATTCACGAGGCCACCACTC }\end{array}$ \\
\hline
\end{tabular}

\subsubsection{Sequencing of the PCR product}

A $10 \mu \mathrm{l}$ sequencing reaction was set up by mixing $5 \mu \mathrm{l}$ purified PCR product (100 $\mathrm{ng}$ ), $3 \mu \mathrm{l}$ BigDye Terminator DNA-sequencing-mix (Applied Biosystems, Damstadt), $1 \mu \mathrm{l}$ GSP3 primer $(1 \mathrm{pmol} / \mu \mathrm{l})$ and $2 \mu \mathrm{l}$ sterilized water. The sequencing PCR was 
performed for 25 cycles as follows: denaturation at $94^{\circ} \mathrm{C}$ for $30 \mathrm{~s}$, annealing at $55^{\circ} \mathrm{C}$ for $15 \mathrm{~s}$, extension at $60^{\circ} \mathrm{C}$ for $4 \mathrm{~min}$.

After the sequencing PCR, the products were precipitated by adding $80 \mu \mathrm{l} \mathrm{H}_{2} \mathrm{O}, 15 \mu \mathrm{l}$ $2 \mathrm{M} \mathrm{NaAC}$ ( $\mathrm{pH} \mathrm{4.0),} 250 \mu \mathrm{l} 100 \%$ ethanol and centrifugation at 14,000×g for $20 \mathrm{~min}$. The pellet was washed once with $250 \mu \mathrm{l} 70 \%$ ethanol and then dissolved in $5 \mu \mathrm{l} \mathrm{H}_{2} \mathrm{O}$. The products were sequenced by using a model 3100 Genetic Analyser (Applied Biosystems, Damstadt).

\subsubsection{Decoy ODN technique}

Double-stranded (ds) decoy ODN were prepared from the complementary singlestranded (ss) phosphorothioate-bonded ODN (Eurogentec, Germany) by melting at $95^{\circ} \mathrm{C}$ for $5 \mathrm{~min}$ followed by a cool-down phase of $3 \mathrm{~h}$ at room temperature. The efficiency of the hybridisation reaction was checked on $2.5 \%$ agarose gels containing $0.1 \%$ ethidium bromide and usually found to exceed $80 \%$. The ds decoy ODN were pre-incubated with the cultured SMC for $4 \mathrm{~h}$ at a concentration of $10 \mu \mathrm{M}$. Thereafter, the decoy ODN-containing medium was replaced with fresh medium containing P3xTB.A7 cells for additional $12 \mathrm{~h}$. The ss sequences of the decoy ODN were as follows (orientation 5' to 3', underlined letters denote phosphorothioatebonded bases): activator protein-1 (AP-1): CGCTTGATGACTCAGCCGGAA, CCAAT/enhancer binding protein (C/EBP) TGCAGATTGCGCAATCTGCA, and NFкB: AGTTGAGGGGACTTTCCCAGGC.

\subsubsection{Western blot analysis}

For Western blot analysis of CD40 protein expression, cells were scraped off the plate into $1 \mathrm{ml} \mathrm{HBSS}$ and then pelleted by centrifugation at $500 \times \mathrm{g}$ for $5 \mathrm{~min}$. The cell pellet was resuspended in lysis buffer [50 mM Tris/ $\mathrm{HCl}(\mathrm{pH} 8.0), 150 \mathrm{mM} \mathrm{NaCl}, 0.1 \%$ SDS, $1 \mathrm{mM}$ DTT, with Proteinase Inhibitor Mix, $30 \mu \mathrm{l} /$ well] and lysed by 5 cycles of freeze/thawing in liquid nitrogen and at $37^{\circ} \mathrm{C}$, respectively. After centrifugation at $13000 \mathrm{~g}$ for $5 \mathrm{~min}$, the supernatant was collected into a new tube. Protein concentration of cell extracts was estimated with the modified Bradford protein assay from BioRad (Munich, Germany) according to the manufacturer's instructions. 
Sample protein $(30 \mu \mathrm{g})$ was denatured by heating to $94^{\circ} \mathrm{C}$ for $5 \mathrm{~min}$ in $1 \times$ loading buffer (Roth, Karlsruhe), and then separated on a $12 \%$ denaturing polyacrylamide gel. Electrophoresis was performed at constant current (20 mA per gel) for approximately $2 \mathrm{~h}$. Subsequently, the separated proteins were electronically transferred to a BioTrace polyvinylidene fluoride transfer membrane (Pall, Dreieich) with Mini-Trans Blot system (Bio-Rad, Muenchen) at $350 \mathrm{~mA}$ for $45 \mathrm{~min}$.

The membrane was blocked with $5 \%$ non-fat milk in PBS at room temperature for $1 \mathrm{~h}$ followed by incubation with the primary antibody at $4^{\circ} \mathrm{C}$ overnight. Human CD40 was detected by using a polyclonal rabbit anti-human CD40 antibody (Research Diagnostics, Flanders, NJ) at a dilution of 1:2,000. HRP-conjugated goat anti-rabbit IgG antibody (Sigma, Germany) was used as the secondary antibody at a dilution of 1:10,000. The detected bands were visualized by SuperSignal ${ }^{\circledR}$ Chemiluminescent Substrate (Pierce, Rockford, USA) followed by exposure of the membrane to X-ray film (Kodak, Germany) for $1 \mathrm{~min}$.

\subsubsection{DNA microarray analysis}

Cytokine pre-stimulated cultured SMC [obtained from passage 3 (p3)] were incubated either with P3xTB.A7 or P3x63Ag8.653 control cells for 12 h. Total RNA was isolated as described in 2.2.1. Human GeneChips ${ }^{\circledR}$ (HG-U95Av2) were purchased from Affymetrix (Santa Clara, CA). Array HG-U95Av2 is comprised of $\approx 12,000$ sequences, most of which are derived from previously characterized fulllength genes $(\approx 10,000)$; each gene is represented by $\approx 16$ non-overlapping oligonucleotide probes (25-mers). RNA conversion to cDNA, labelling with CY3 or CY5 fluorescence dye, hybridization, and signal intensity normalization were carried out at the Core Unit DNA Technologies of the IZKF/University of Leipzig. Data indicating presence or absence of gene expression (presence/absence call, determined by Affymetrix) were sorted, compared, and statistically analyzed by using the Affimetrix Microarray Suite 5.0 software. Genes were considered up-regulated or down-regulated if the expression was changed at least 1.9-fold from control. Fold change in this case indicates the relative difference in signal intensity for the gene between the two samples. Only reliable and consistent mean values from three independent experiments with an appropriate standard deviation were considered. Data with low signal intensity, high background, and high variability among 
experiments were eliminated. Genes were designated according to the annotations from Affymetrix and the GenBank databases.

\subsubsection{ELISA}

For the quantitative determination of IL1-1ß concentrations, THP-1 cells were collected from the lower compartment of the cell-interaction chamber (2.1.8). For detection of a humoral stimulatory factor SMC were cultured in 6-well plates until reaching confluence followed by stimulation with IFN $\gamma(1000 \mathrm{U} / \mathrm{ml})$ plus TNF $\alpha$ (100 $\mathrm{U} / \mathrm{ml}$ ) for $24 \mathrm{~h}$, medium exchange for $12 \mathrm{~h}$ and subsequent exposure to the P3xTB.A7 or P3x63Ag8.653 control cells $\left(1 \times 10^{6}\right.$ cells $\left./ \mathrm{mL}\right)$ for $12 \mathrm{~h}$. Supernatant was taken, centrifuged, diluted in a ratio of $1: 1$ with fresh DMEM medium containing $15 \%$ FCS and incubated in a new 6-well plate with THP-1 cells $\left(1 \times 10^{6}\right.$ cells $\left./ \mathrm{mL}\right)$ for $12 \mathrm{~h}$. After this time THP-1 cells were collected, washed twice with PBS and lysed with lysis buffer [1 M Tris- $\mathrm{HCl}(\mathrm{pH} 8.0), 5 \mathrm{M} \mathrm{NaCl}, \mathrm{NP}-40$, glycerol, proteinase inhibitor mix]. After centrifugation (13000 rpm, $80 \mathrm{~min},+4^{\circ} \mathrm{C}$ ), the supernatant containing the cell lysate was taken and used for IL-1ß immunoassay. To this end the human IL-1ß QuantiGlo ${ }^{\circledR}$ ELISA Kit (R\&D Systems, Wiesbaden, Germany) was used according the manufacturer's instructions. Standards (dilution series from $0.5 \mathrm{pg} / \mathrm{ml}$ to $5000 \mathrm{pg} / \mathrm{ml}$ ) and samples $(100 \mu \mathrm{l})$ were pipetted into the wells pre-coated with IL-1ß monoclonal antibody. After incubation on the horizontal orbital micro plate shaker (IkaLabortechnik, Germany) (0.12" orbit, 500 rpm, 2 h, ambient temperature) and repeated washing steps, an enzyme-linked polyclonal antibody specific for IL-1ß was added to the wells and incubated (for $3 \mathrm{~h}$ at ambient temperature with constant shaking). The final step was performed by adding luminol/peroxide substrate solution to the wells for $30 \mathrm{~min}$ and light was produced in proportion to the amount of IL-1ß bound in the initial step. A microplate luminometer was used to measure the intensity of the light emitted.

\subsection{Statistical analysis}

Unless indicated otherwise, results are expressed as mean \pm SEM of $n$ independent observations (i.e. samples from different batches of SMC). Statistical evaluation was performed by Student's t-test for unpaired data with the Instat for Windows ${ }^{\mathrm{TM}}{ }^{\text {version }}$ 
3.05 statistics software package (GraphPad Software, San Diego, USA) and a p value $<0.05$ was considered statistically significant. 


\section{Results}

\subsection{Characterisation of thymus vascular smooth muscle cells}

Smooth muscle cells derived from the thymus veins of children (not older than 2 years of age) were the model used throughout this study. The veins were isolated from thymus tissue that had to be resected in the course of heart surgery. The cells were isolated as described and used for experiments up to passage 4. Examination by phase-contrast microscopy revealed that the cells uniformly display the typical 'hill and valley' pattern of cultured SMC and form multilayers upon reaching confluence.

A

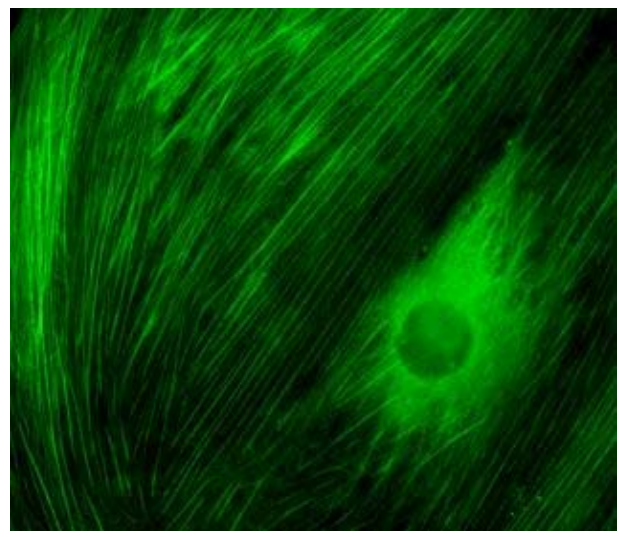

B

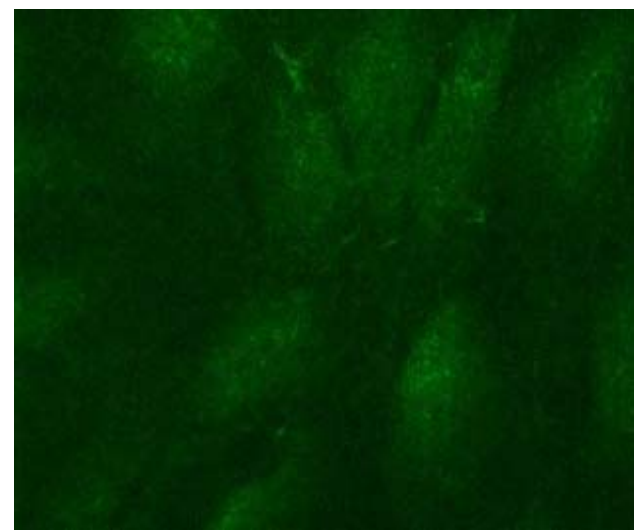

Figure 1. Typical results of immunofluorescence analyses for SMC and endothelial cells markers: Immunofluorescence analysis was performed as described in Materials and methods. A) Smooth muscle $\alpha$-actin expression in human cultured SMC. B) SMC stained for von Willebrand factor (essentially negative). Original x 400.

In addition, immunofluorescence analysis for smooth-muscle $\alpha$-actin and von Willebrand factor, a marker for endothelial cells, was routinely performed. Whereas $98-100 \%$ of the cells stained positive for smooth-muscle $\alpha$-actin with the typical fibrillar pattern, they were essentially negative for von Willebrand factor (human cultured endothelial cells were used as a positive control for this factor, not shown).

\subsection{Stimulation of SMC with IFN $\gamma /$ TNF $\alpha$ induces expression of CD40}

As outlined in 1.4, the central aim of this work was to elucidate the functional consequences of CD40 activation in SMC under pro-inflammatory conditions. 
To this end, first the expression of CD40 under these conditions was studied. RTPCR analysis resulted in the amplification of a DNA fragment with the expected size of approximately $380 \mathrm{bp}$ already under control conditions, i.e. in untreated SMC. Subsequent sequence analysis confirmed the identity of the amplified product. The abundance of CD40 mRNA was markedly increased after exposure of the SMC to pro-inflammatory cytokines. Shown is the combination of TNF $\alpha(100 \mathrm{U} / \mathrm{mL})$ and IFN $\gamma$ (1000 U/mL) for $24 \mathrm{~h}$ (Fig. 2).

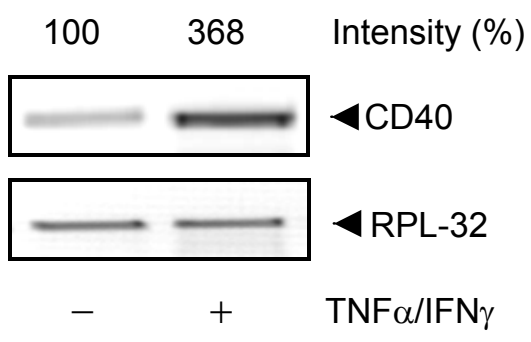

Figure 2. Expression of CD40 mRNA in SMC under basal conditions and following stimulation with TNF $\alpha(100 \mathrm{U} / \mathrm{mL})$ and IFN $\gamma(1000 \mathrm{U} / \mathrm{mL})$ for $24 \mathrm{~h}$. The relative intensity (\% of control, measured by densitometry) is indicated at the top of the panel. The figure depicts the result of one representative experiment. Similar results were obtained in 2 additional experiments with different batches of SMC. The cDNA of RPL-32 was used as an internal standard to normalize the cDNA load in the individual samples.

Moreover, cytokine induced up-regulation of CD40 in SMC was time-dependent, reaching a plateau phase after approximately $24 \mathrm{~h}$ (Fig. 3).

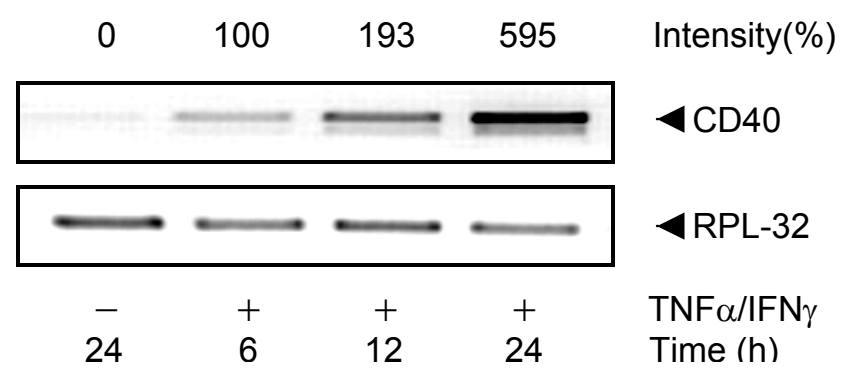

Figure 3. Time-dependent effect of TNF $\alpha(100 \mathrm{U} / \mathrm{mL})$ and IFN $\gamma(1000 \mathrm{U} / \mathrm{mL})$ on CD40 mRNA expression. The relative intensity (\% of TNF $\alpha / \mathrm{IFN} \gamma$ treatment after $6 \mathrm{~h}$ ) was measured by densitometry, indicated at the top. The figure depicts the result of one representative experiment. Similar results were obtained in 2 additional experiments with different batches of SMC. RPL-32 was used as an internal standard as described above.

To confirm these data on the protein level, Western blot analyses were performed. CD40 protein was detected as an immunoreactive band corresponding to a 
molecular mass of approximately $49 \mathrm{kDa}$. In contrast to CD40 mRNA, the protein was only detectable upon exposure of the SMC to IFN $\gamma(1000 \mathrm{U} / \mathrm{mL})$ alone or IFN $\gamma$ (1000 U/mL) plus TNF $\alpha$ (100 U/mL), (Fig. 4).

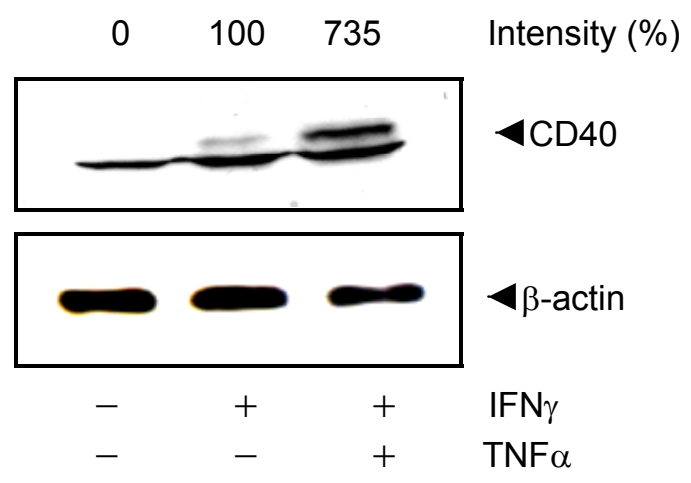

Figure 4. Expression of CD40 protein under basal conditions and following stimulation with IFN $\gamma(1000 \mathrm{U} / \mathrm{mL})$ or IFN $\gamma$ plus TNF $\alpha(100 \mathrm{U} / \mathrm{mL})$ for $24 \mathrm{~h}$. Representative Western blot analysis. Loading and transfer of equal amounts of protein in each lane was verified by reprobing the membrane with an anti- $\beta$-actin antibody.

Like CD40 mRNA expression, cytokine-induced CD40 protein expression was rather slow reaching a significant level only after $24 \mathrm{~h}$ (Fig. 5). Although higher amounts of TNF $\alpha(1000 \mathrm{U} / \mathrm{mL}$ plus $100 \mathrm{U} / \mathrm{mL} \mathrm{IFN} \gamma)$ resulted in a more prominent induction of CD40 protein expression (Fig. 5 right lane), this cytokine combination was omitted from further experiments as the viability of the cultured SMC was negatively affected (not shown). Thus, for all further experiments the cytokine combination $1000 \mathrm{U} / \mathrm{mL}$ IFN $\gamma$ plus $100 \mathrm{U} / \mathrm{mL}$ TNF $\alpha$ was employed.

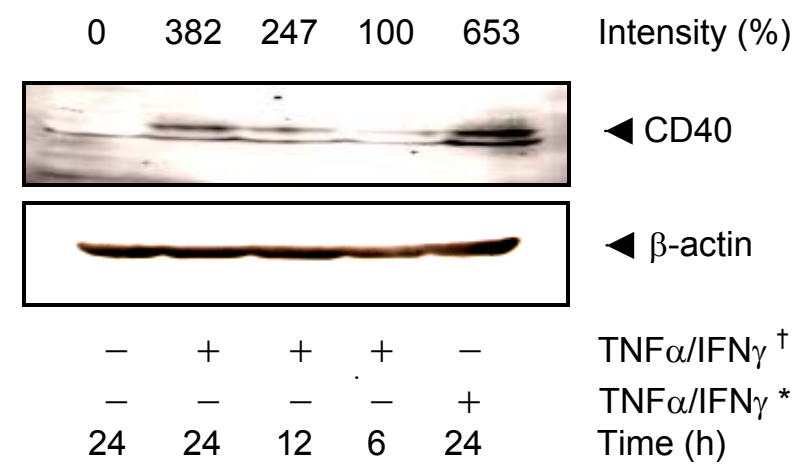

Figure 5. Time course of CD40 protein expression in TNF $\alpha /$ IFN $\gamma$ primed SMC. Expression of CD40 protein was both time and stimulus dependent ( ${ }^{\dagger}$ refers to 100 $\mathrm{U} / \mathrm{ml} \mathrm{TNF} \alpha$ and $1000 \mathrm{U} / \mathrm{ml} \mathrm{IFN} \gamma$; ${ }^{*}$ refers to $1000 \mathrm{U} / \mathrm{ml}$ TNF $\alpha$ and $100 \mathrm{U} / \mathrm{ml} \mathrm{IFN} \gamma$ ). Representative Western blot analysis. Loading and transfer of equal amounts of protein in each lane was verified by reprobing the membrane with an anti- $\beta$-actin antibody. 


\subsection{CD40-induced expression of MCP-1 and MMP-3 in SMC}

After having characterized cytokine-induced expression of CD40 in cultured human SMC, the next step was to analyse which gene products were expressed upon CD40 activation. For this purpose, SMC were first exposed to the cytokine mixture (100 $\mathrm{U} / \mathrm{ml} \mathrm{TNF} \alpha$ and $1000 \mathrm{U} / \mathrm{ml} \mathrm{IFN} \gamma$ ) found to optimally induce CD40 expression over 24 $\mathrm{h}$, followed by a $12 \mathrm{~h}$ resting phase in which the cytokines were removed from the cell supernatant.

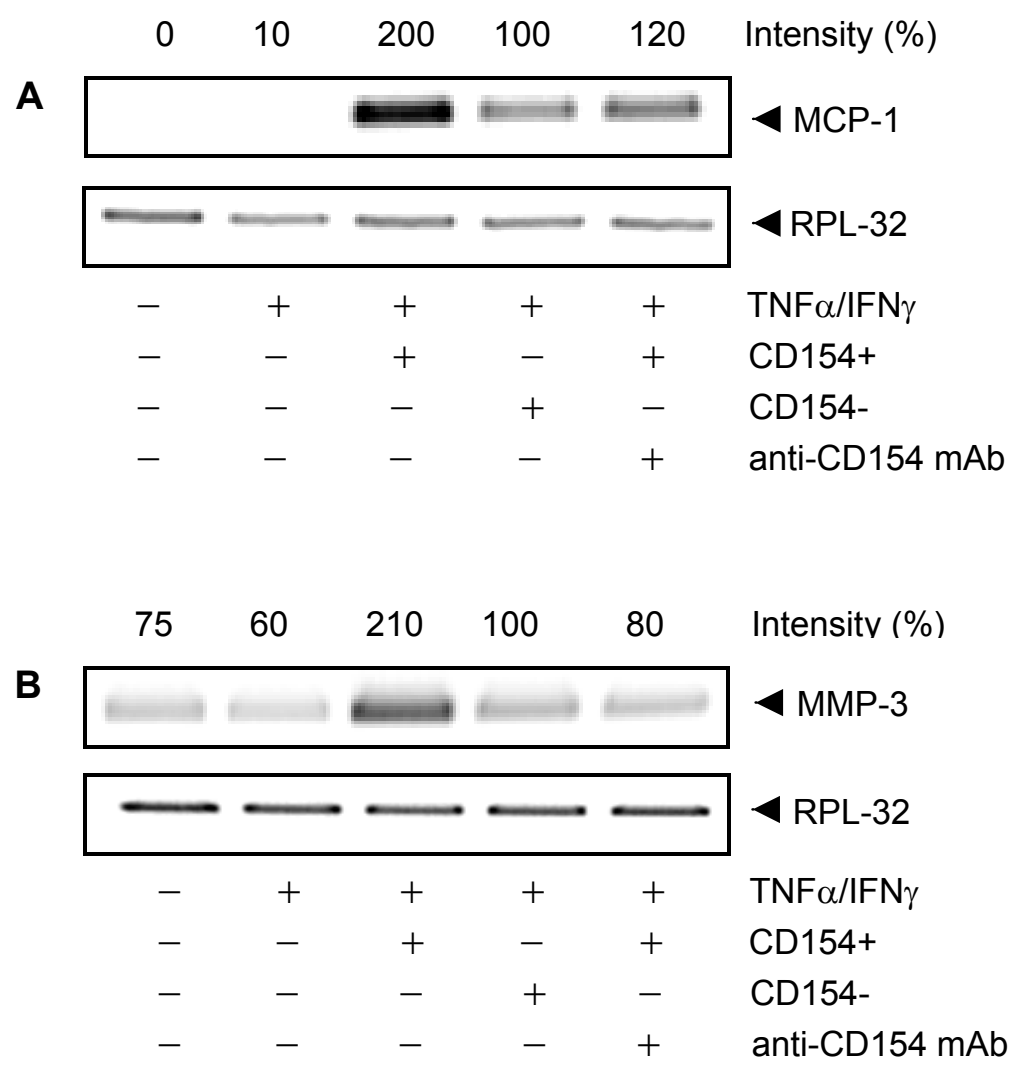

Figure 6. CD154 up-regulation of the expression of (A) MCP-1 and (B) MMP-3 in cytokine-stimulated SMC. SMC pre-stimulated with TNF $\alpha / \mathrm{IFN} \gamma$ for $24 \mathrm{~h}$ were coincubated with P3xTB.A7 cells (CD154+), P3x63Ag8.653 cells (CD154-), or P3xTB.A7 cells plus $40 \mu \mathrm{g} / \mathrm{mL}$ of the neutralizing anti-CD154 antibody. The cDNA coding for RPL32 was used as an internal standard. MCP-1 and MMP-3 mRNA abundance are expressed as the percentage of the control (i.e. SMC treated with TNF $\alpha / \mathrm{IFN} \gamma$ plus nontransfected myeloma cells). Virtually identical results were obtained in 2 further experiments each with different batches of cells.

To activate CD40, the cytokine-primed SMC were co-incubated with the P3xTB.A7 mouse myeloma cells stably transfected with human CD154 $\left(1 \times 10^{6}\right.$ cells $\left./ \mathrm{mL}\right)$. Coincubations with P3x63Ag8.653 control cells or with P3xTB.A7 cells in the presence 
of a neutralising monoclonal anti-CD154 antibody ( $40 \mu \mathrm{g} / \mathrm{mL})$ were used as a control. This amount of antibody has previously been determined to completely inhibit CD154-induced CD40-signalling in human cultured endothelial cells (Lienenlueke et al., 2000).

Next, a broad and representative spectrum of gene products known to be upregulated in SMC under pro-inflammatory conditions was analysed by RT-PCR: the PDGF-receptor $\alpha$, the matrix proteins fibronectin and tenascin $C$, the modulator of secondary hemostasis thrombospondin, the chemokine MCP-1 and the matrix metalloprotease MMP-3. Surprisingly, activation of CD40 resulted in the upregulation of only MCP-1 and MMP-3 expression in the cultured SMC, suggesting a specific and selective capacity of CD40 to change the gene expression profile of these cells.

\subsection{Signalling pathway involved in CD40 dependent MMP-3 activation}

To study the signalling mechanisms involved in CD40-induced gene expression, MMP-3 was chosen as a readout. SMC were first exposed to several agents known to interfere with cAMP signalling.

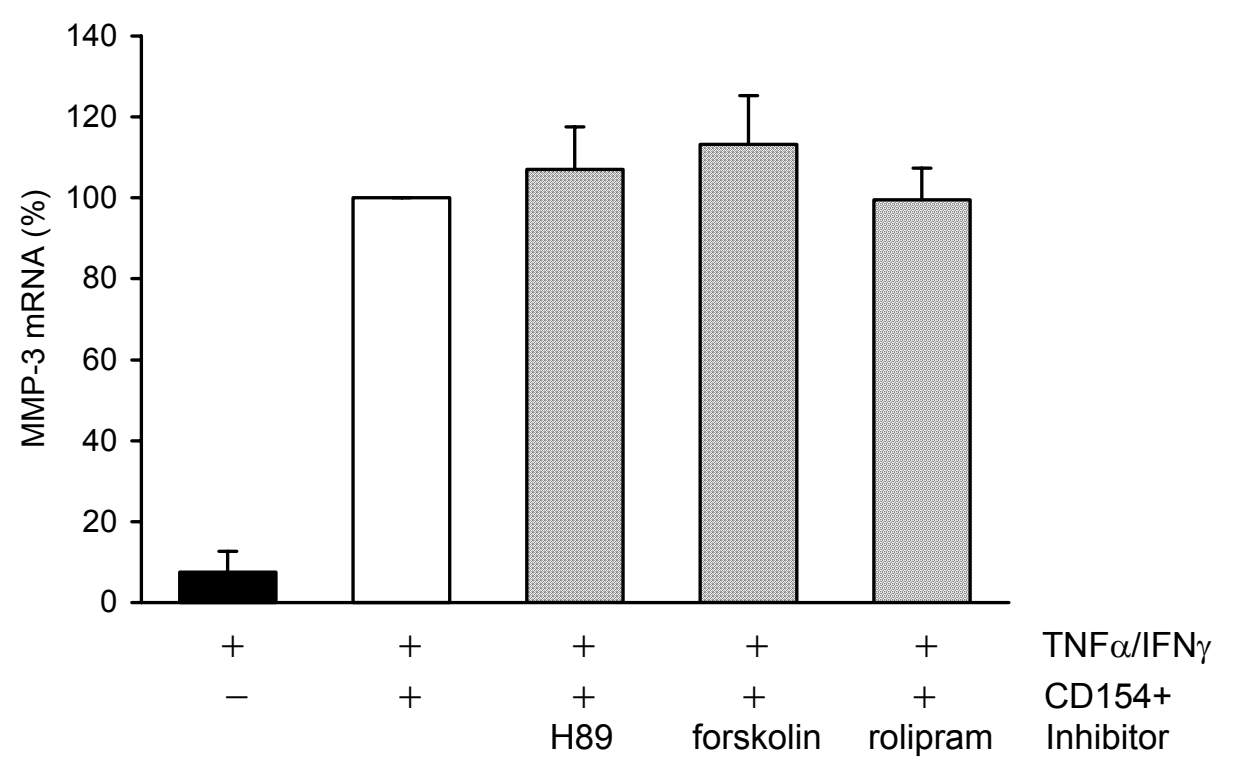

Figure 7. Effects of cAMP pathway inhibitors on CD154-induced MMP-3 expression in cultured SMC. The CD40-expressing cells were pre-treated with H89 (1 $\mu \mathrm{M}, \mathrm{n}=3)$, forskolin $(10 \mu \mathrm{M}, \mathrm{n}=4)$ or rolipram $(12.5 \mu \mathrm{M}, \mathrm{n}=4)$ for $1 \mathrm{~h}$ before exposure to the P3xTB.A7 cells (CD154+) as described before (Fig. 6). Statistical summary of MMP-3 mRNA abundance, expressed as percentage of CD40-stimulated SMC; bars show the standard error. 
Neither a specific protein kinase A inhibitor (H89) nor an adenylyl cyclase activator (forskolin) or a phosphodiesterase IV inhibitor (rolipram) exerted inhibitory effects on CD154-induced MMP-3 expression, as shown in Fig. 7.

The putative involvement of other protein kinases was examined by using the corresponding inhibitors. These experiments revealed that neither inhibition of the classical protein kinase C (PKC inhibitor RO 31-8220) or MAP-kinase pathway (MEK$1 \rightarrow$ ERK1/ERK2; PD 98059 was used as a specific inhibitor of MEK-1) nor that of the Jun kinase/SAPK pathway (JNK inhibitor SP 600125) affected CD154-induced MMP3 expression in the cultured SMC (Fig. 8).

However, both Src tyrosine kinase (herbimycin A) and p38 MAP kinase (p38-MAPK; specific inhibitor: SB 202190) activation seemed to be essential for CD154-induced MMP-3 expression. Thus each inhibitor reduced CD154-induced MMP-3 expression by approximately $70 \%$ (Fig. 8). The PI-3 kinase inhibitor wortmannin, on the other hand, had no effect on CD154-induced MMP-3 expression, while the Rho kinase inhibitor, Y 27632, augmented this almost 2 fold (Fig. 9).

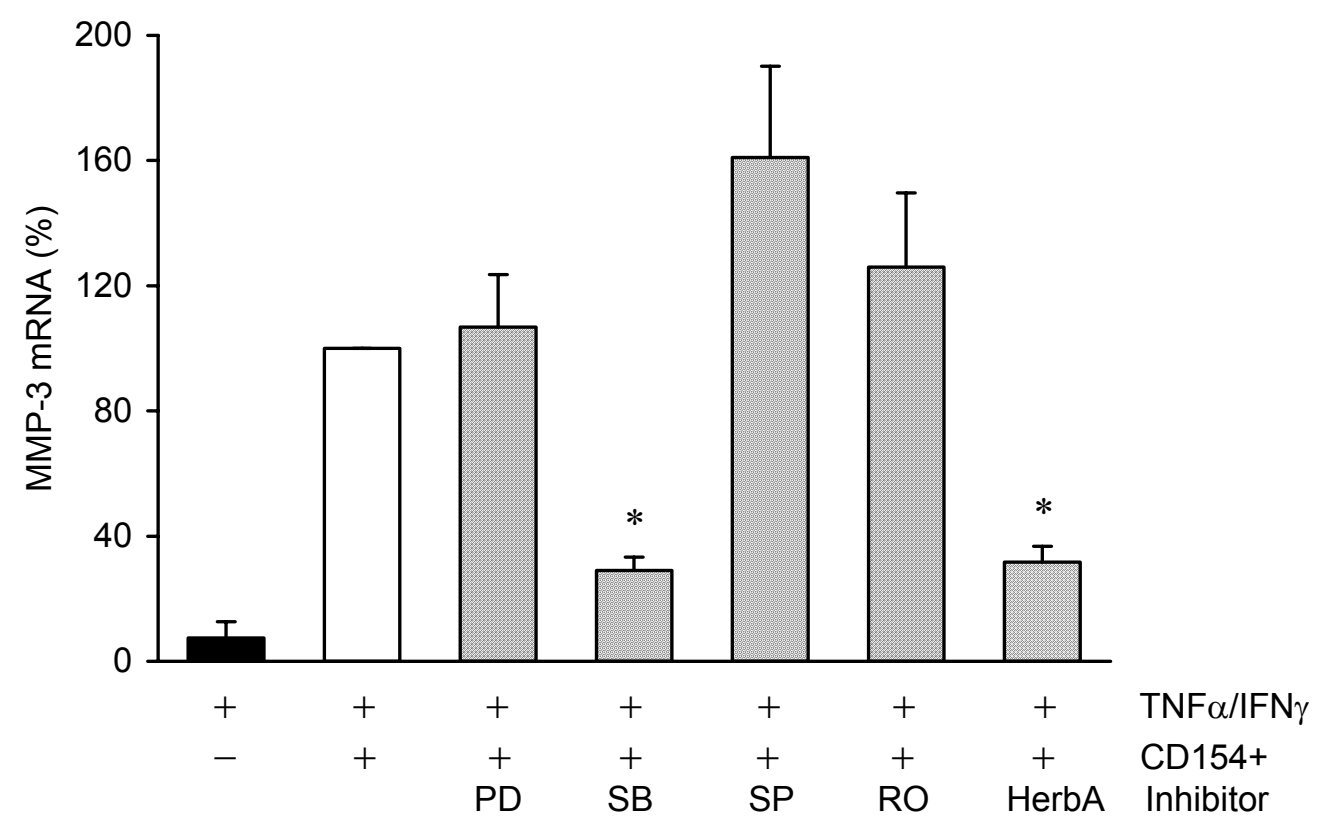

Figure 8. Effects of different protein kinase inhibitors on CD154-mediated MMP-3 expression in the cultured SMC. Cells expressing CD40 were pre-treated with PD 98059 (PD, $50 \mu \mathrm{M}, \mathrm{n}=4$ ), SB 202190 (SB, $10 \mu \mathrm{M}, \mathrm{n}=5)$, SP 600125 (SP, $20 \mu \mathrm{M}, \mathrm{n}=3$ ), RO 31-8220 (RO, $1 \mu \mathrm{M}, \mathrm{n}=5)$ or herbimycin $\mathrm{A}$ (HerbA, $1 \mu \mathrm{M}, \mathrm{n}=6)$ for $1 \mathrm{~h}$ before exposure to the P3xTB.A7 cells (CD154+) as described before (Fig. 6). MMP-3 mRNA abundance in the individual samples is compared to that in CD154-stimulated control cells (set to $100 \%$ ). ${ }^{*} \mathrm{P}<0.05$ versus positive control. 


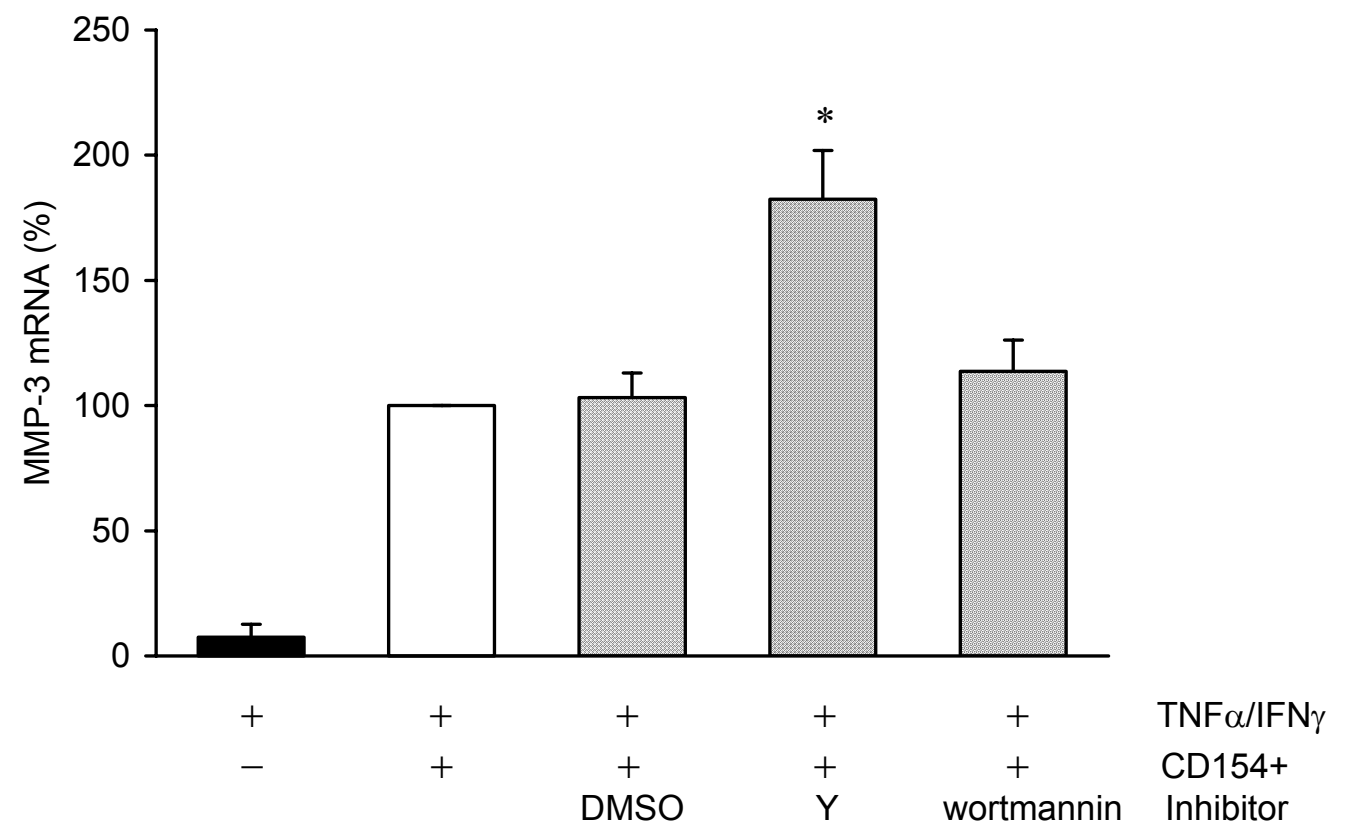

Figure 9. Effects of Y27632 on CD154-induced MMP-3 expression in the cultured SMC. CD40-expressing cells were pre-treated with $Y 27632(Y, 10 \mu M, n=7)$, wortmannin $(100 \mathrm{nM}, \mathrm{n}=3$ ) or the vehicle (DMSO, $1 \mu \mathrm{L} / \mathrm{mL}, \mathrm{n}=3$ ) for $1 \mathrm{~h}$ before exposure to the P3xTB.A7 cells (CD154+) as described before (Fig. 6). MMP-3 mRNA abundance in the individual samples is expressed relative to that in CD154-stimulated control cells (set to $100 \%$ ). ${ }^{*} \mathrm{P}<0.05$ versus positive control.

\subsubsection{Increase in MMP-3 mRNA expression induced by CD154 stimulation is due to transcriptional activation}

Based on the finding that p38 MAPK is involved in CD154-induced MMP-3 expression (Fig. 8), the hypothesis was tested that p38 MAPK exerts this effect through mRNA stabilization (Reunanen et al., 2002) rather than activation of transcription. To determine whether the CD154-induced increase in steady state levels of MMP-3 mRNA is due to a decrease in MMP-3 mRNA degradation, the stability of MMP-3 mRNA was measured in the presence of the inhibitor of transcription actinomycin $D$ (ActD). Cells were treated with P3xTB.A7 mouse myeloma cells for $12 \mathrm{~h}$, after which time ActD (final concentration $1 \mu \mathrm{M}$ ) was added. Total RNA was isolated 0-12 $\mathrm{h}$ after the addition of ActD and analysed by RT-PCR. MMP-3 mRNA abundance decreased to approximately $60 \%$ over $12 \mathrm{~h}$, indicating that the increase in MMP-3 mRNA observed after CD40 activation is due to increased synthesis (i.e. transcription) rather than stabilization of MMP-3 mRNA. 


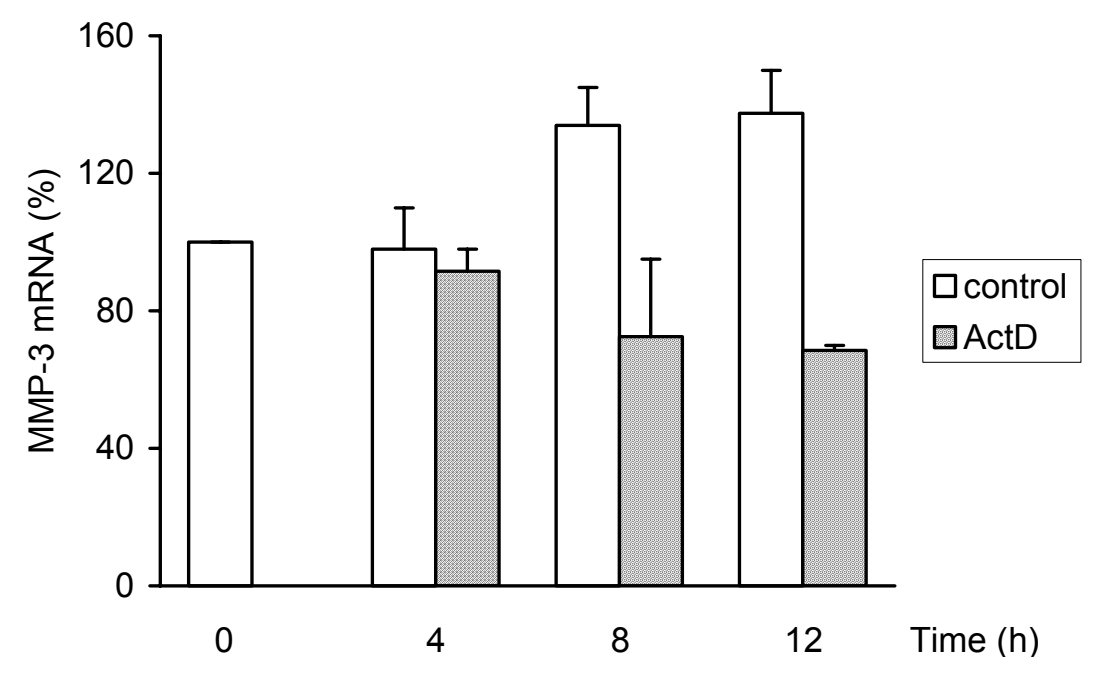

Figure 10. Analysis of MMP-3 mRNA stability. ActD was added after $12 \mathrm{~h}$ stimulation of the cultured SMC with CD154+, and cells were collected at the indicated time points. MMP-3 mRNA abundance in the individual samples is expressed relative to that in CD154-stimulated control cells at time 0 (set to $100 \%$ ).

To confirm that CD154-induced MMP-3 expression is due to an increase in $m m p-3$ gene transcription, cells were first treated with ActD $(1 \mu \mathrm{M})$ for $1 \mathrm{~h}$ to inhibit transcription followed by exposure to the P3xTB.A7 myeloma cells for $12 \mathrm{~h}$.

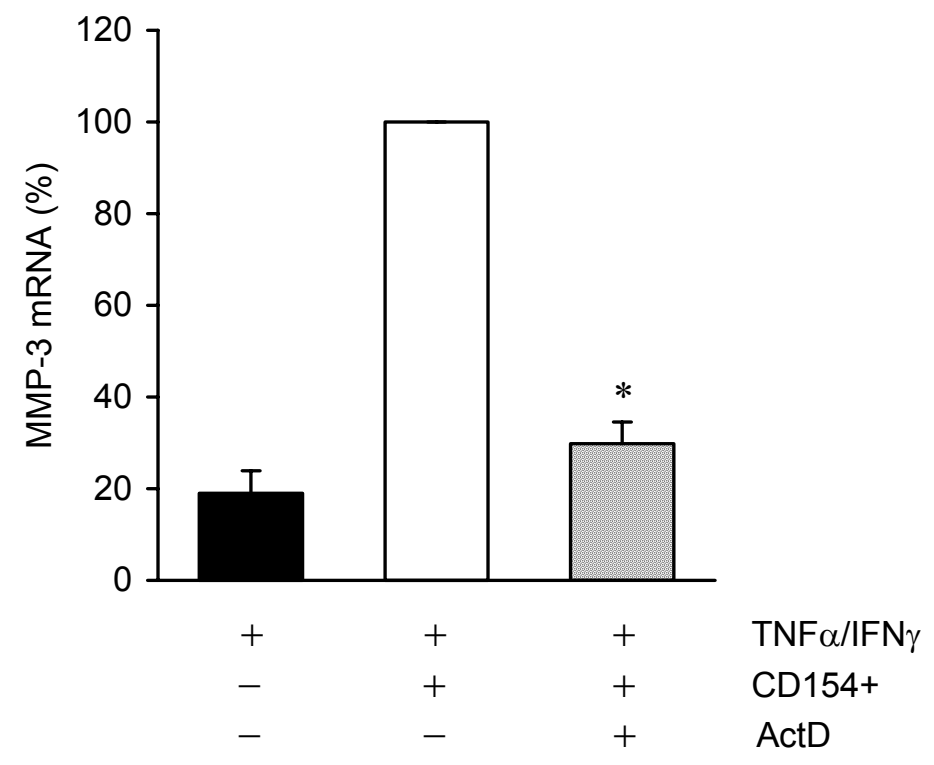

Figure 11. Effect of Actinomycin D (ActD) on $\mathbf{m m p - 3}$ gene transcription. ActD was applied at $1 \mu \mathrm{M}$ to the SMC $1 \mathrm{~h}$ prior to CD40 stimulation. Statistical summary of three individual experiments. ${ }^{*} \mathrm{P}<0.05$ versus positive control (CD154-stimulated $\left.S M C\right)$. For experimental details refer to Fig. 6 . 
CD154-induced MMP-3 expression was almost completely abolished in the presence of ActD when compared to CD40 stimulation only, suggesting that the increase in MMP-3 mRNA expression in response to CD40 activation is indeed due to an increase in $m m p-3$ gene transcription.

\subsubsection{CD154-induced MMP-3 mRNA expression does not require de novo protein synthesis}

To evaluate whether the induction by CD154 of mmp-3 gene transcription requires de novo synthesis of a transcription factor, CD40-expressing SMC were treated with cycloheximide $(1 \mu \mathrm{g} / \mathrm{mL}) 1 \mathrm{~h}$ prior to addition of the P3xTB.A7 myeloma cells to stimulate MMP-3 mRNA expression for $12 \mathrm{~h}$. Inhibition of protein synthesis significantly augmented rather than inhibited MMP-3 mRNA expression (Fig. 12), suggesting that a latent transcription factor(s) is involved in CD154 stimulation of $m m p-3$ gene transcription.

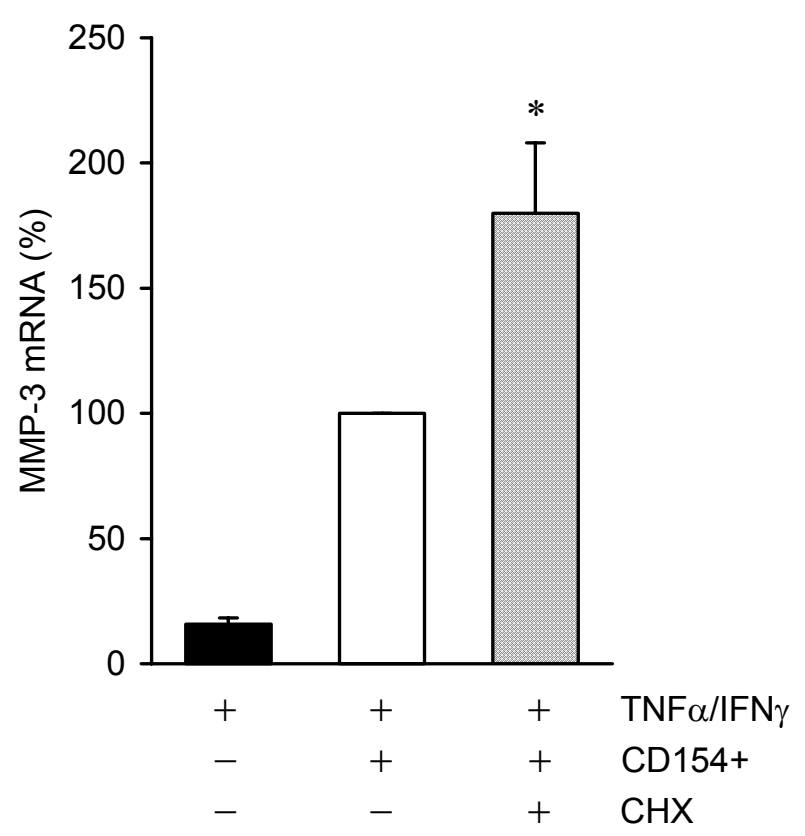

Figure 12. Superinduction by cycloheximide (CHX) of CD154-stimulated MMP-3 mRNA expression. $\mathrm{CHX}$ pre-treatment $(1 \mu \mathrm{g} / \mathrm{mL})$ was done for $1 \mathrm{~h}$ and MMP-3 mRNA expression monitored by RT-PCR analysis over $12 \mathrm{~h}$ in SMC exposed to the P3xTB.A7 mouse myeloma cells $(C D 154+)$. Statistical summary $(n=3)$. ${ }^{*} P<0.05$ versus positive control (CD154-stimulated SMC). 


\subsubsection{Effects of decoy ODN}

In an attempt to characterize the transcription factor(s) involved in CD154-induced MMP-3 expression in the cultured SMC, the decoy oligonucleotide (dODN) technique was employed. Decoy-ODNs are short double-stranded DNA molecules that readily enter cells in vitro and in vivo without any additional transfection reagent. They mimic the binding site of their target transcription factor in the cellular DNA. As a consequence, the transcription factor is effectively neutralised when interacting with the dODN instead of its natural DNA-binding site.

Three different transcription factors were hypothesized to play a role in MMP-3 mRNA expression, namely AP-1, C/EBP and NF- $\mathrm{KB}$, because it is known that they are activated by CD40 or c-src/p38 MAPK. Therefore, dODN against these three factors at a final concentration of $10 \mu \mathrm{M}$ were applied for $4 \mathrm{~h}$ prior to CD154 stimulation. None of them had an effect on MMP-3 mRNA levels (Fig. 13). To check the activity of the dODN applied, MCP-1 mRNA expression was assessed in parallel since it is known that NF-KB and C/EBP are involved in the transriptional regulation of this gene (Schwabe et al., 2001). MCP-1 expression was effectively reduced by the dODN directed against both NF-kB and C/EBP, thus confirming their biological activity.

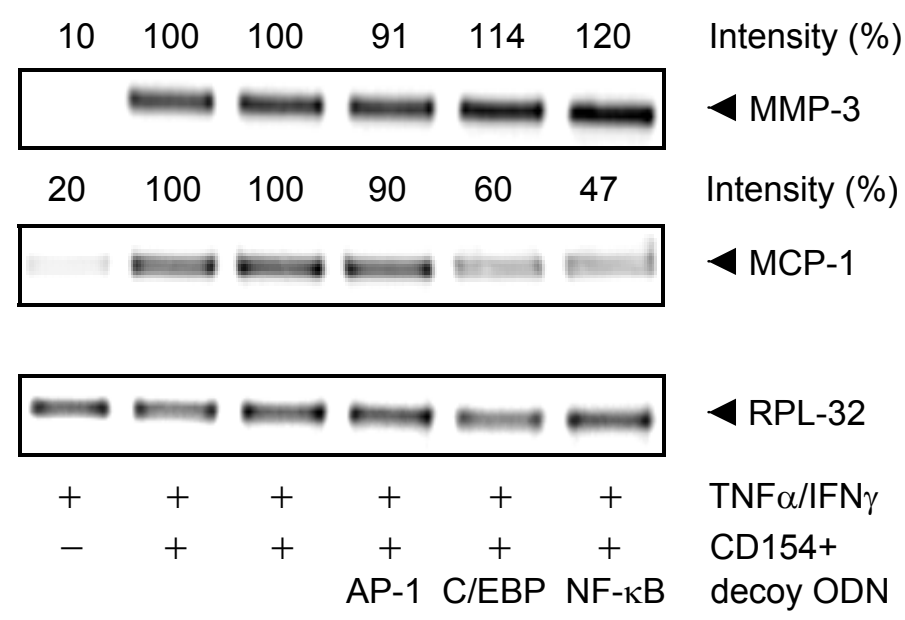

Figure 13. Effects of the indicated consensus decoy ODN on CD40 induced MMP. 3 and MCP-1 mRNA expression. The figure is representative of 3 independent experiments. The cDNA encoding RPL-32 was used as an internal standard. 


\subsection{Gene expression profile in SMC after CD40 ligation analysed by DNA microarray}

To obtain a more detailed view of the gene expression profile in CD154-stimulated SMC, a DNA microarray analysis was performed using the human GeneChip Expression Array by Affymetrix which detects approximately 10,000 individual human genes. Differential gene expression was analysed in three independent batches of SMC essentially treated as described in 3.3. In brief, the SMC (passage $3,10^{7}$ cells collected from 6 -well plates to obtain approximately $10 \mu \mathrm{g}$ of total RNA) were primed with TNF $\alpha$ plus IFN $\gamma(100$ and $1000 \mathrm{U} / \mathrm{mL}$, respectively) for $24 \mathrm{~h}$ followed by cytokine removal and the exposure to either the P3xTB.A7 mouse myeloma cells (CD154+) or P3x63Ag8.653 control cells (CD154-) for $12 \mathrm{~h}$ before lysis and extraction of total RNA.

Analysis of the 3 microarray experiments was designed as follows. To be counted as truly differentially expressed, a given gene product had to accomplish three criteria:

1) Expression of the gene product in question had to be uniformly high in the individual microarray analysis in order to exclude hybridisation artefacts and background signals.

2) The difference (increase or decrease) in signal strength had to be at least 1.9fold.

3) The two criteria defined above had to be fulfilled in all three independent microarray analyses performed.

As a result, 36 gene products out of 10,000 were scored to be differentially expressed. Of these, 2 were down- and 34 up-regulated. The results are summarized in tables 3 and 4 . Interestingly, most of the differentially expressed gene products are associated with inflammatory reactions. 
Differentially expressed gene products in CD154-stimulated SMC according to DNA microarray analysis

Table 3: Secreted mediators, cell adhesion molecules,

receptors and pro-inflammatory molecules

\begin{tabular}{|l|c|l|}
\hline Gene product & Fold \pm S.E.M & Class/Function \\
\hline MIP-1 $\alpha$ & $2.7 \pm 0.9$ & C-C Chemokine ligand-3 \\
\hline MIP-3 $\alpha$ & $2.9 \pm 0.3$ & C-C Chemokine ligand-20 \\
\hline RANTES & $2.1 \pm 0.3$ & C-C Chemokine ligand-5 \\
\hline GM-CSF & $4.1 \pm 2.3$ & Cytokine involved in monocytes activation \\
\hline GRO- $\beta$ & $2.0 \pm 0.5$ & Chemokine (C-X-C motif) ligand 2 \\
\hline GRO- $\gamma$ & $3.3 \pm 0.5$ & C-X-C Chemokine ligand-3 \\
\hline MCP-2 & $1.9 \pm 0.5$ & C-C Chemokine ligand-8 \\
\hline Interleukin-1 $\beta$ & $3.0 \pm 1.6$ & Member of the interleukin 1 cytokine family \\
\hline Interleukin-15 & $2.1 \pm 0.0$ & Cytokine of the four-helix bundle family \\
\hline Interleukin-15r $\alpha$ & $1.9 \pm 0.4$ & Binds IL-15 with high affinity \\
\hline VCAM-1 & $1.9 \pm 0.3$ & Ligand for VLA-4 \\
\hline E-Selectin & $7.2 \pm 3.0$ & Selectin family of cell adhesion molecules \\
\hline Ninjurin & $2.6 \pm 0.4$ & Adhesion molecule \\
\hline CCR7 & $4.9 \pm 0.8$ & C-C Chemokine receptor-7 \\
\hline CD40 & $2.2 \pm 0.5$ & Member of TNF receptor superfamily \\
\hline TNFAIP6 & $2.8 \pm 0.4$ & Member of hyaluronan-binding protein family \\
\hline Fractalkine & $1.9 \pm 0.2$ & C-X-3C chemokine \\
\hline Cox-2 & $3.4 \pm 2.3$ & Key enzyme in prostaglandin biosynthesis \\
\hline MMP-12 & $2.7 \pm 0.8$ & Member of MMP family \\
\hline VEGF & $2.9 \pm 1.6$ & Mitogen primarily for vascular endothelial cells \\
\hline
\end{tabular}

Table 4: Intracellular gene products involved in signal transduction and other gene products induced or repressed (printed in italics)

\begin{tabular}{|c|c|c|}
\hline Gene product & Fold \pm S.E.M & Class/Function \\
\hline Jun-B & $2.0 \pm 0.1$ & Participates in AP-1 transcriptional activation \\
\hline p50-NF-кB homolog & $2.6 \pm 0.5$ & Related to $\mathrm{p} 50 / \mathrm{p} 105 \mathrm{NF}-\mathrm{kB}$ \\
\hline NF- $\kappa B$ subunit $p 100$ & $2.1 \pm 0.3$ & Transcription factor \\
\hline TRAF1 & $2.8 \pm 0.8$ & Signal transducer \\
\hline Zinc finger protein 36 & $2.0 \pm 0.8$ & Involved in growth factor response regulation \\
\hline RGP4 & $0.5 \pm 0.1$ & Inhibits G- protein-mediated MAP kinase activation \\
\hline MacMarcks & $2.0 \pm 0.3$ & Signal transducer mediating cell adhesion \\
\hline Follistatin-related protein & $2.3 \pm 0.8$ & Member of the follistatin-module-protein family \\
\hline Fas/Apo 1 & $1.9 \pm 0.4$ & Member ot TNF receptor superfamily \\
\hline Diubiquitin & $3.1 \pm 1.1$ & Ubiquitin family \\
\hline Id1 & $0.5 \pm 0.1$ & Member of the Id HLH-family of proteins \\
\hline Hypothetical protein & $2.0 \pm 0.3$ & Similar to MT1E metallothionein 1E \\
\hline TNFAIP2 & $2.4 \pm 0.2$ & Plays a role in myeloid development \\
\hline GC20 & $2.3 \pm 0.8$ & Translation initiation factor \\
\hline IAP-1 & $3.3 \pm 1.8$ & Suppressor of apoptosis \\
\hline $\begin{array}{l}\text { Dual-specificity protein } \\
\text { phosphatase }\end{array}$ & $2.1 \pm 0.1$ & Member of protein-tyrosine phosphatases \\
\hline
\end{tabular}




\subsubsection{Validation of the DNA microarray experiments}

To confirm the DNA microarray data, mRNA expression of seven CD154-inducible gene products selected for their putative involvement in the development of atherosclerosis was analysed further by RT-PCR (Fig. 14). The identity of all PCR fragments was verified by direct sequencing (not shown). The RT-PCR data fully corroborated the changes in gene expression detected by the DNA microarray technique (Fig. 14). Moreover, RT-PCR analysis confirmed that these gene products were up-regulated to nearby the same extent as detected by the DNA microarray (Table 5).

IL15 receptor $\alpha$-chain mRNA appeared as a double band. As the PCR primer pair used for this analysis amplified a DNA product including exon-2 of the il-15r $\alpha$ gene, this may be explained through differential splicing of the mRNA. IL-15ra-chain mRNA can exist in eight different transcripts resulting from exon-splicing mechanisms within the il-15r $\alpha$ gene. From these transcripts two main classes of transcripts can be distinguished that do or do not contain the exon 2-coding sequence (Dubois et al., 1999).

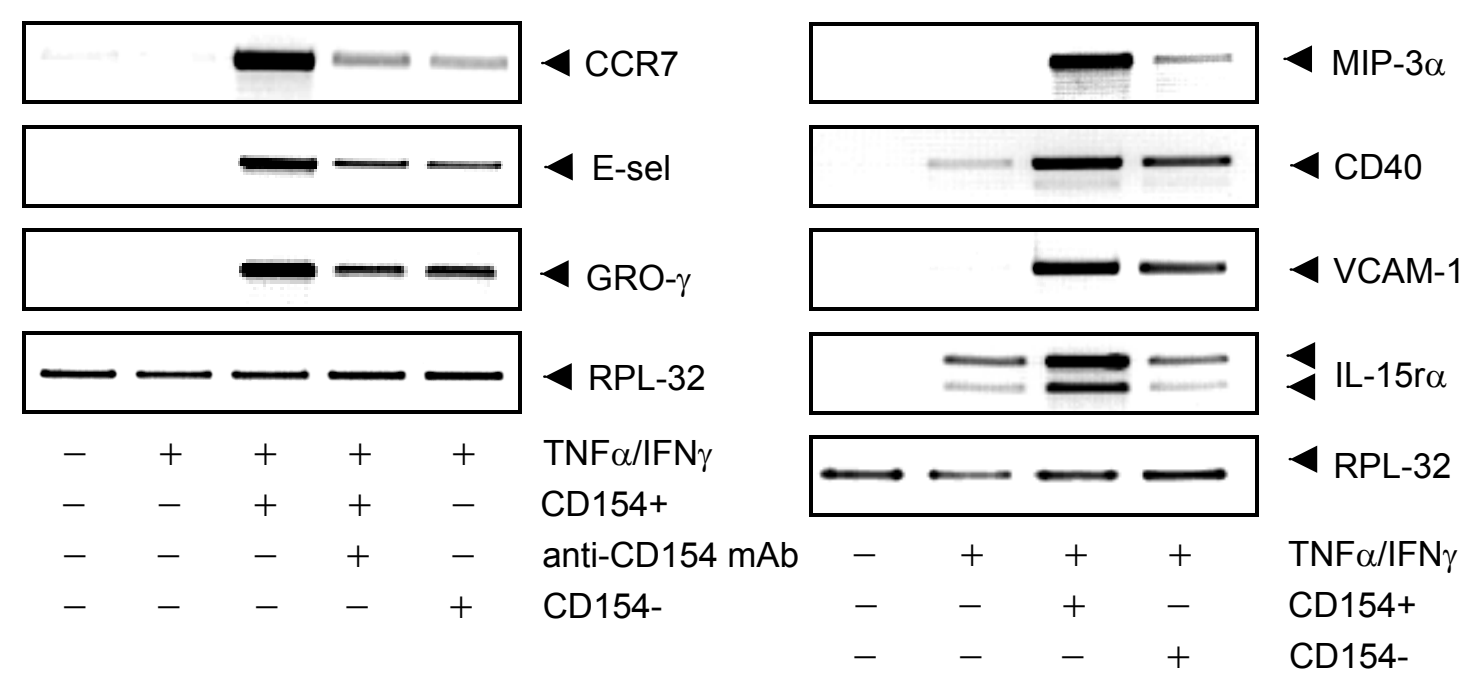

Figure 14. RT-PCR analysis of 7 gene products randomly selected from the list of inducible gene products characterized to be CD154-sensitive in SMC by DNA microarray analysis. For experimental details refer to Fig. 6. Additional incubation with the neutralizing anti-CD154 antibody demonstrates that induction of gene expression is mediated via CD40 activation. The figures are representative of two independent experiments. The cDNA encoding RPL-32 was used as an internal standard. 
Interestingly, the microarray results could also be confirmed for CD40 itself, thus CD40 activation also induces its own expression (Fig. 14). The increase in VCAM-1 expression was additionally confirmed on the protein level by immunofluorescence analysis (data not shown).

Table 5. Comparision of data obtained by DNA microarray and RT-PCR analysis with respect to the relative increase in gene expression. Values represent the mean of 3 different experiments ("mean of two experiments).

\begin{tabular}{|l|c|c|}
\hline Gene product & $\begin{array}{c}\text { Fold increase by DNA } \\
\text { microarray (range) }\end{array}$ & $\begin{array}{c}\text { Fold increase by RT- } \\
\text { PCR analysis (*) }\end{array}$ \\
\hline CCR7 & $4.9(4.0-5.5)$ & 7.1 \\
\hline E-selectin & $7.2(4.8-10.6)$ & 7.5 \\
\hline GRO- $\gamma$ & $3.3(2.8-3.7)$ & 3.3 \\
\hline MIP-3 $\alpha$ & $2.9(2.6-3.1)$ & 4.4 \\
\hline CD40 & $2.2(1.6-2.7)$ & 2.2 \\
\hline IL15receptor & $1.9(1.8-2.4)$ & 3.0 \\
\hline VCAM-1 & $1.9(1.4-2.4)$ & 1.9 \\
\hline
\end{tabular}

\subsection{CD40-mediated SMC activation of monocytes}

As described above, CD154 stimulation resulted in an increase in expression of several pro-inflammatory chemokines, their receptors and adhesion molecules in the human cultured SMC. To understand the implications of these findings in the light of vascular inflammation, namely atherosclerosis, a cell interaction assay (Fig. 15) was set-up. SMC cultured on a porous membrane were pre-stimulated with IFN $\gamma$ plus TNF $\alpha$ followed by co-incubation with the P3xTB.A7 or P3x63Ag8.653 control cells for $12 \mathrm{~h}$. After this time, the SMC were thoroughly washed in order to completely remove the mouse myeloma cells and then co-incubated with THP1 pre-monocytic cells (1 $\left.1 \times 10^{6} \mathrm{cells} / \mathrm{ml}\right)$. Recombinant MCP-1 $(100 \mathrm{ng} / \mathrm{mL})$ was added to the bottom well of the transwell system to serve as a chemoattractant for the monocytes. After $12 \mathrm{~h}$ THP-1 cells that had moved to the bottom well were collected and used for further analysis. 

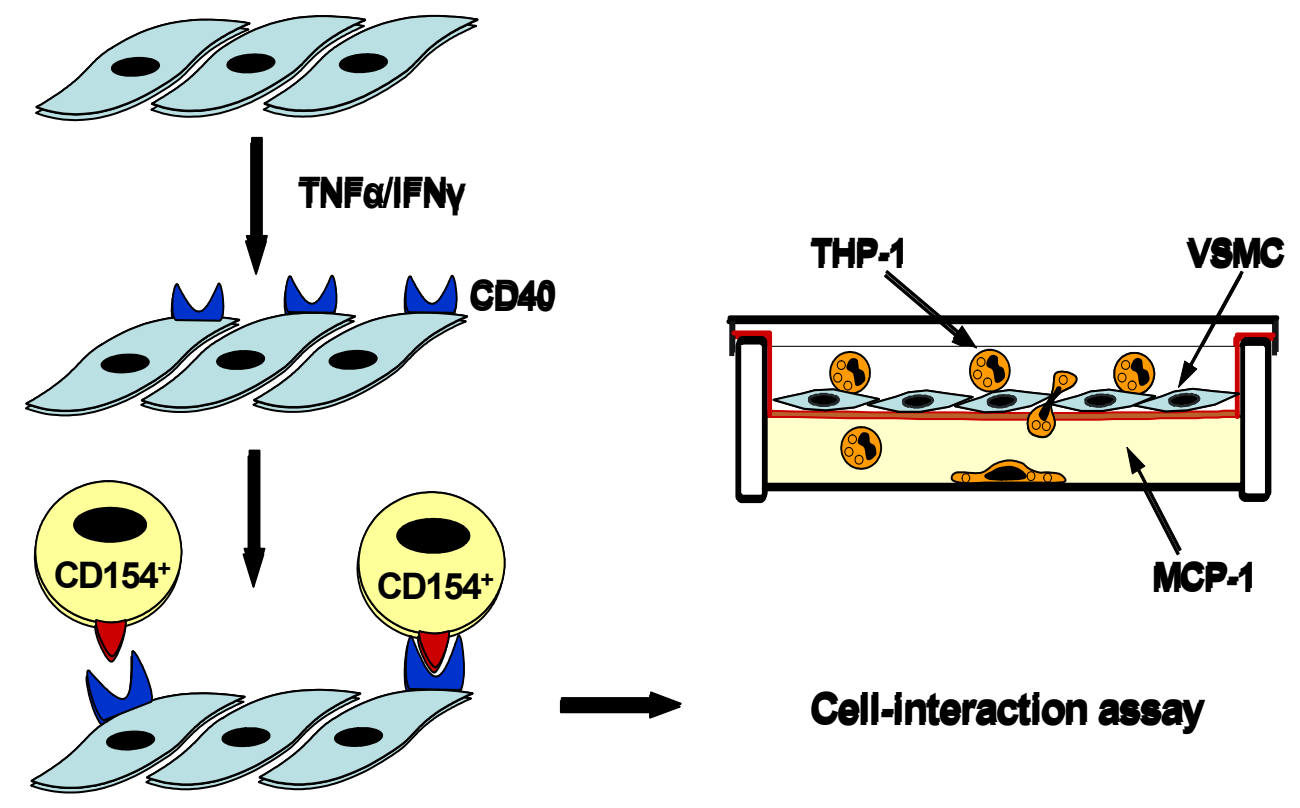

Cell-interaction assay

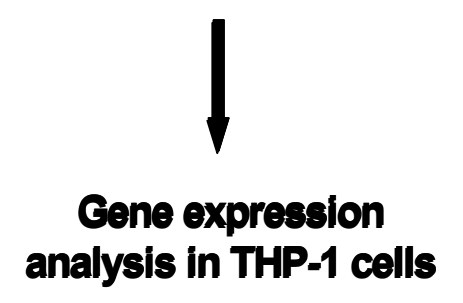

Figure 15. Outline of the cell interaction assay.

Interestingly, no difference was observed in the number of migrating THP-1 cells through the SMC layer irrespective of whether these had been or had not been exposed to CD154. Typically $10 \%$, i.e. approximately $10^{5} \mathrm{THP}-1$ cells migrated into the lower compartment after $12 \mathrm{~h}$ of incubation, indicating that the recombinant MCP. 1 added to the lower compartment was a highly effective chemoattractant.

RT-PCR analysis revealed that THP-1 cells which came into contact with SMC previously stimulated by CD154, became activated themselves, whereas THP-1 cells interacting with control SMC remained essentially quiescent. As a readout for monocyte activation, IL-23 p19 and IL-1ß mRNA expression was monitored in the transmigrated THP-1 cells and found to be markedly up-regulated (Fig. 16A and B). $\mathrm{IL}-1 ß$ was also up-regulated on the protein level as demonstrated by ELISA (Fig. 16 C) To avoid a possible contamination with SMC-derived soluble IL-1ß, cellassociated IL-1ß protein was determined in THP-1 cell lysates. 
A

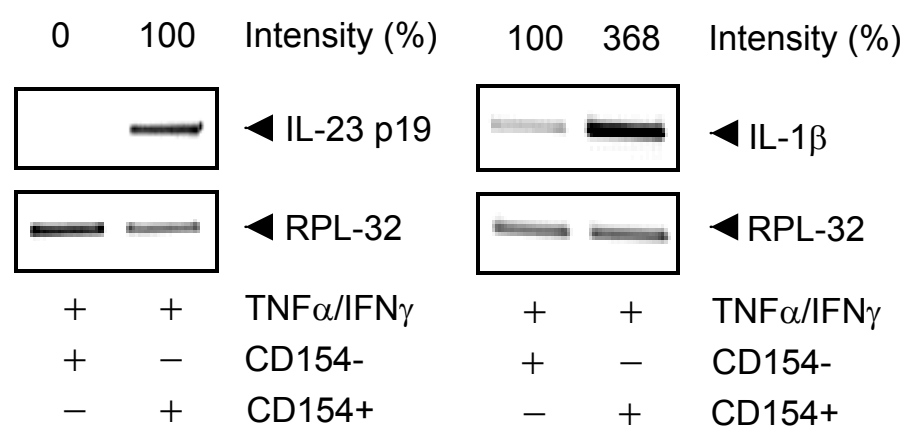

C

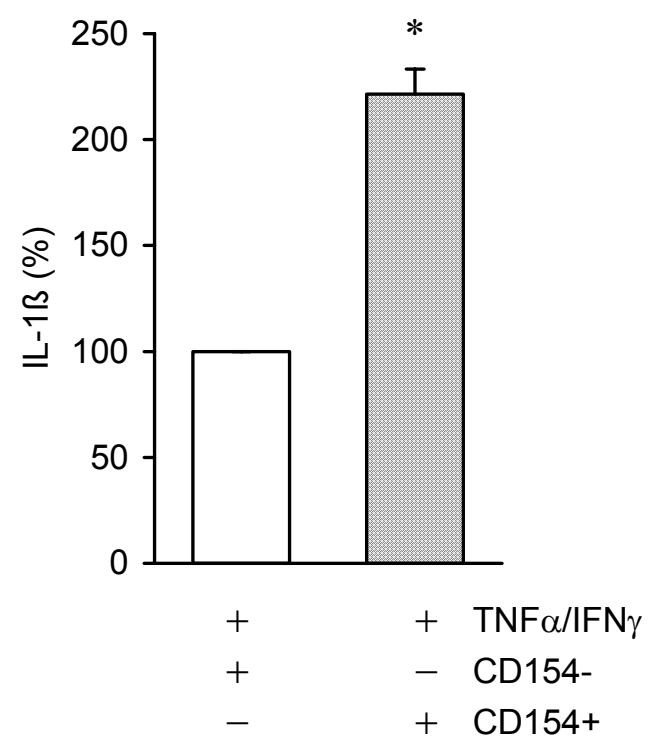

Figure 16. Effects of CD40 activation in a SMC-THP-1 cell-interaction assay. THP1 cells were harvested $12 \mathrm{~h}$ after beginning of the experiment followed by RT-PCR analysis of (A) IL-23 p19 and (B) IL-1ß mRNA expression in the transmigrated THP-1 cells. Data are representative for 5 experiments. (C) ELISA of IL-1ß protein abundance in the lysate of the transmigrated THP-1 cells $(n=4)$. Protein concentration of cell extracts was estimated with the modified Bradford protein assay and equalized for each sample. ${ }^{*} \mathrm{P}<0.05$ versus negative control (i.e. SMC treated with TNF $\alpha / \mathrm{IFN} \gamma$ and exposed to the CD154- myeloma cells).

However, CD154 stimulation of the cultured SMC up-regulated the expression of both adhesion molecules (necessary for cell-to-cell interaction) and chemokines (same of which are thought to be highly effective chemoattractants for monocytes).

The next series of experiments, therefore, was designed to discriminate between SMC activation of THP-1 cells through cell-to-cell interaction (mediated by, e.g., adhesion molecules) or via the release of a humoral factor (e.g., a chemokine). To this end, the conditioned medium from SMC pre-stimulated with TNF $\alpha$ plus IFN $\gamma$ followed by co-incubation with the CD154-expressing P3xTB.A7 cells or the corresponding control cells was collected and incubated with the THP-1 cells for 12 h. Five gene products, i.e. IL-23 p 19, IL-1ß, IL-8, CD40 and MCP-1 were monitored on the mRNA level (Fig. 17). In addition, IL-1ß protein expression was determined (Fig. 18). 

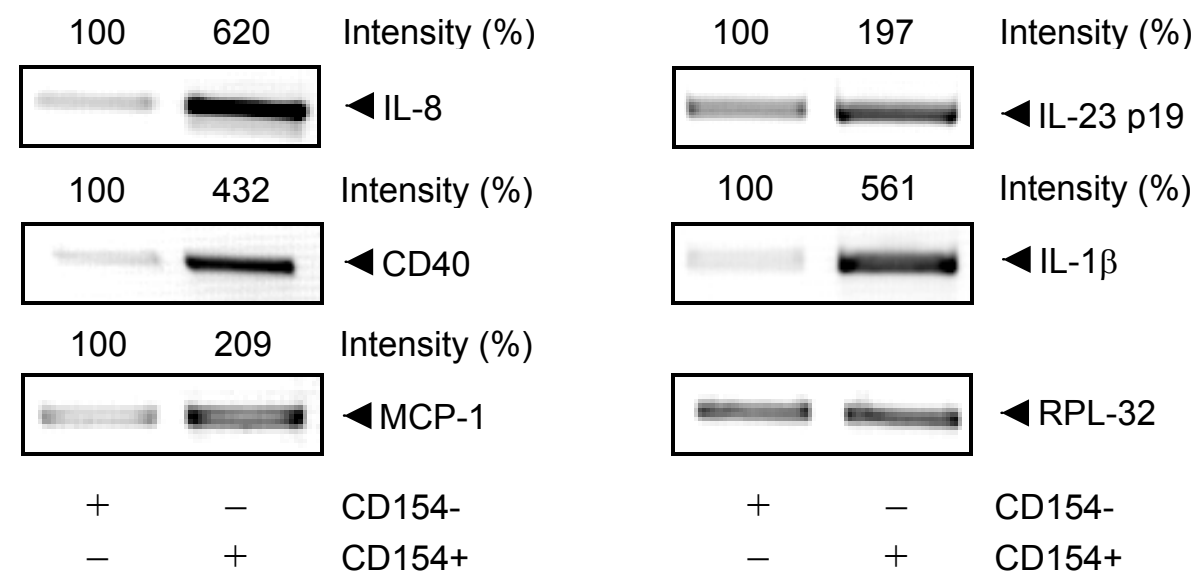

Figure 17: The conditioned medium of CD154-stimulated SMC induces the expression of IL-23 p19, IL-1ß, IL-8, CD40 and MCP-1 in THP-1 cells. CD40expressing SMC were co-incubated with the CD154-expressing P3xTB.A7 cells or the corresponding control cells for $12 \mathrm{~h}$. Thereafter THP-1 cells were exposed to the conditioned medium diluted 1:1 with normal culture medium for $12 \mathrm{~h}$ followed by RTPCR analysis with RPL-32 as an internal standard. Data are representative for 3 individual experiments.

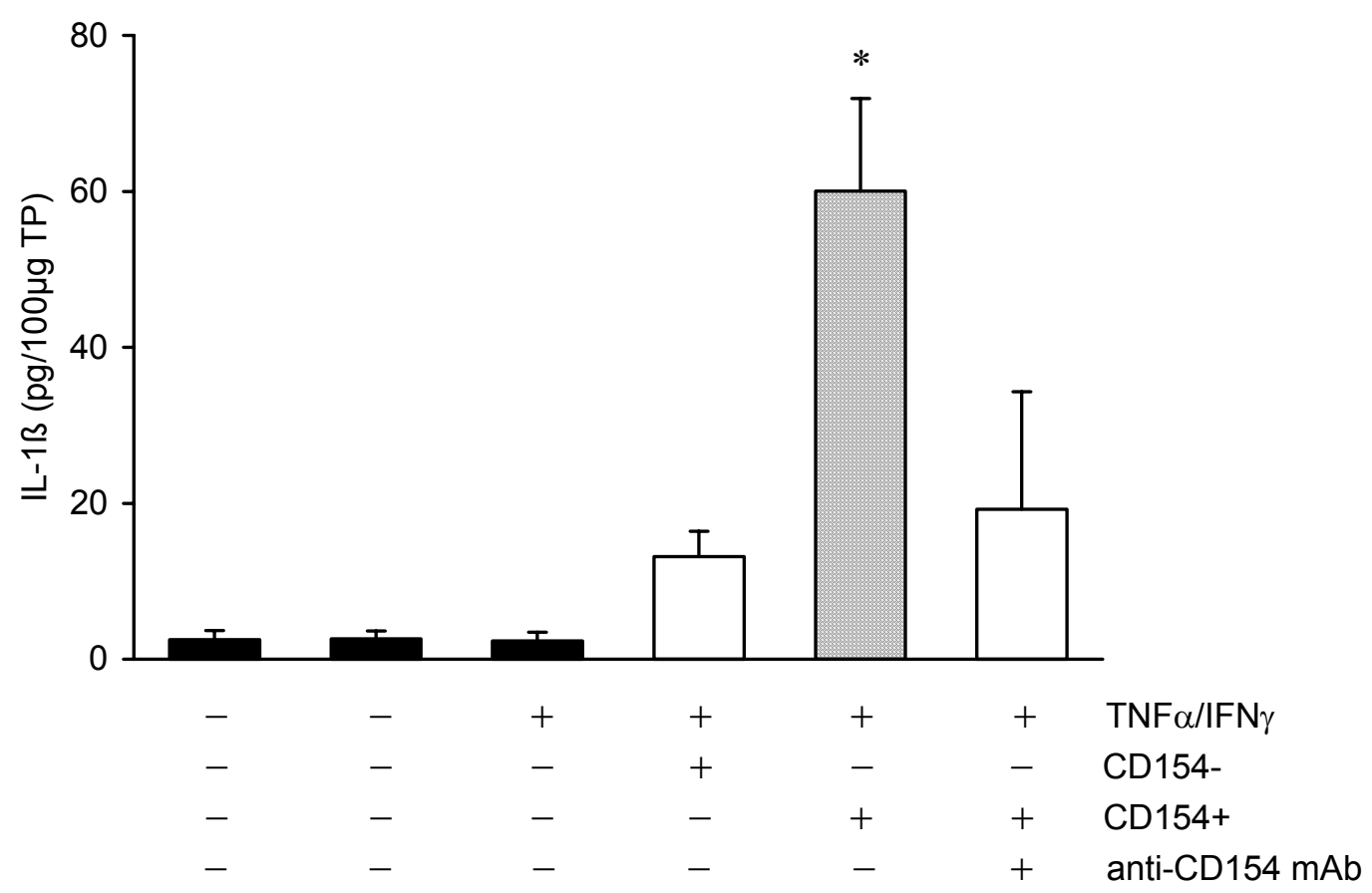

Figure 18. SMC supernatant-induced IL-1ß protein expression in THP-1 cells. Cell-associated IL-1 $\beta$ protein expression was measured by ELISA as the amount (in pg) per $100 \mu \mathrm{g}$ of total protein (TP). Statistical summary $(n=5)$. For experimental details see Fig. 17. ${ }^{*} \mathrm{P}<0.05$ versus negative control (i.e. conditioned medium of nonstimulated SMC).

IL-1 $\beta$ protein expression induced by the conditioned medium of CD154-stimulated SMC was even more pronounced as in the cell interaction assay. This result strongly 
suggests, that SMC-induced THP-1 activation is mediated by a soluble factor (i.e. most probably a chemokine and/or a cytokine) produced by SMC in response to CD40 activation and not by direct cell-to-cell interaction.

\subsubsection{Effects of GM-CSF and IL-15 on CD40 and IL-8 expression}

Which of the soluble factors expressed by SMC in response to CD40 activation are responsible for monocyte activation? To test potential candidates causing CD40 or IL-8 mRNA expression in THP-1 cells, the same experimental approach was chosen as described above except that neutralizing antibodies against GM-CSF $(20 \mu \mathrm{g} / \mathrm{mL})$ and IL-15 $(2 \mu \mathrm{g} / \mathrm{mL})$ were employed in addition. An anti- $\beta$-actin antibody was used $(20 \mu \mathrm{g} / \mathrm{mL})$ as a negative control (not shown). The anti-GM-CSF antibody, in contrast to the antibody directed against IL-15, clearly affected IL-8 expression in response to the SMC supernatant while CD40 expression was attenuated only weakly (Fig. 19).

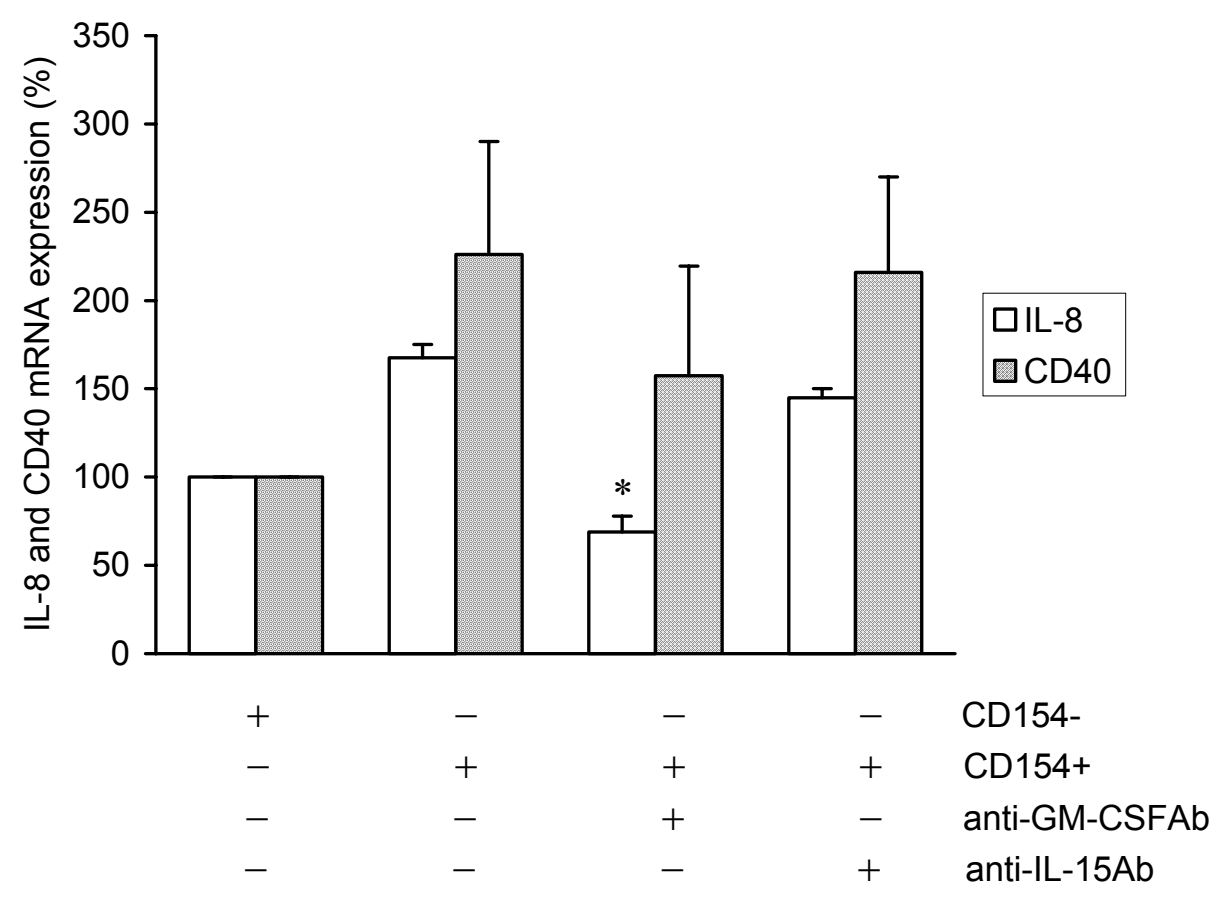

Figure 19. Effects of GM-CSF and IL-15 on CD40 and IL-8 expression. Supernatants of SMC incubated with P3x63Ag8.653 or P3xTB.A7 cells were preincubated for $1 \mathrm{~h}$ with anti-IL-15 antibody or anti-GM-CSF antibody, applied to THP-1 cells for $12 \mathrm{~h}$ as described and the corresponding gene products were detected in the THP- 1 cell lysates by RT-PCR. Statistical summary $(n=3)$. ${ }^{*} P<0.05$ versus $C D 154+$. 


\section{Discussion}

\subsection{The experimental model}

The experimental model used in this study was cultured smooth muscle cells isolated from human thymus veins. To ensure that the cells were not contaminated with associated fibroblasts and endothelial cells, they were routinely monitored for the expression of smooth muscle $\alpha$-actin, a marker for SMC, and for von Willebrand factor, a marker for endothelial cells. Although fibroblasts also contain smooth muscle $\alpha$-actin, the staining pattern in fully differentiated SMC is very different as compared to that in fibroblasts. Typically, $100 \%$ of the cells stained positive for $\alpha$ actin with approximately $98 \%$ showing the fibrillar pattern typical for SMC. On the other hand, the cells were essentially negative for von Willebrand factor, thereby ruling out a contamination by endothelial cells.

Besides SMC homogeneity, 3 additional criteria had to be met for the experiments described.

First, to achieve an 'activated state' of the SMC associated with a significant expression of CD40, the cells had to be pre-incubated with a combination of proinflammatory cytokines (TNF $\alpha / \mathrm{IFN} \gamma$ ). On the one hand, these cytokines cause an increase in expression of numerous pro-inflammatory gene products (for review see, e.g., Libby et al., 1995). On the other hand, truly CD40-induced gene products could nevertheless and only be detected in these cells after induction of CD40 expression (see below). Pertaining to the situation in vivo, it can be stated that vascular SMC will be exposed to these cytokines under conditions of an inflammatory response in the vessel wall. Thus, cultured SMC exposed to TNF $\alpha /$ IFN $\gamma$ provide a simple, but relevant model for the analysis of the role of CD40 in the course of vascular inflammation.

Secondly, CD40 activation in SMC had to be achieved by the use of mouse myeloma cells expressing human CD154 because no trimeric soluble ligand or fusion protein was available. As a control, identical cells not expressing CD154 were used in every experiment, evidencing that all effects addressed to CD154 indeed were specific. Moreover, special care was taken that no gene (e.g., human specific PCR primers) or protein derived from myeloma cells was detected. 
Thirdly, THP-1 cells were used as monocytic cells to monitor functional consequences of SMC CD40 activation. This cell line is well characterized as a monocyte pre-cursor (Tsuchiya et al., 1980.). Although the use of freshly isolated peripheral monocytes might have been desirable, the inherent variability of cells derived from different donors proves a major problem. Therefore, THP-1 cells were chosen as the second best choice for the cell-to-cell interaction assays described herein.

\subsection{CD40 expression in SMC}

Activation of CD40 by its specific ligand CD154 present mainly on T-cells and platelets plays an important role in the pathogenesis of atherosclerosis (Mach et al., 1998). Human endothelial cells express functional CD40 under basal conditions in vitro (Karmann et al., 1995) and this expression is significantly up-regulated in the presence of pro-inflammatory cytokines (Wagner et al., 2002). As SMC are well characterized to play a major role in the development and progression of atherosclerosis, the aim of this study was to answer the question whether CD40 might also play a role in atherosclerosis-related activation of SMC. Under basal conditions, SMC express only very little CD40 mRNA while CD40 protein was not detectable (Western blot analysis). When exposed to pro-inflammatory cytokines such as IFN $\gamma$ and/or TNF $\alpha$, i.e. mimicking an inflammatory response in the vessel wall, CD40 abundance was markedly increased both on the mRNA and protein level, suggesting that expression of CD40 is induced de novo by these cytokines in the cultured SMC. This finding is at variancy with a previous study showing basal expression of CD40 protein in human SMC (Mach et al., 1997.). The reason for this difference might be, besides the protocol for isolating the cells, the source of the cells used in this study. Mach et al. used cells derived from saphenous vein grafts left over from aortocoronary bypass surgery. These veins usually stem from elderly patients suffering from atherosclerosis at least in the heart, so that SMC isolated from such vessels might be chronically activated by high levels of circulating pro-inflammatory mediators present in these patients.

However, one important result derived from these experiments was that CD40, as in endothelial cells, is inducible by pro-inflammatory cytokines also in vascular SMC. 


\subsection{CD40 induced by IFN $\gamma$ and TNF $\alpha$ is functionally active}

The first step assessing the effects of CD40 activation in human SMC was the analysis of MCP-1 and MMP-3 expression. These gene products were chosen because it is well known that both play an important role in macrophage activation and inflammatory remodelling processes in human blood vessels (Russell et al., 1993; Galis et al., 1994). Indeed, expression of MMP-3 and MCP-1 in the SMC was up-regulated solely after CD40 activation, because it was induced only by mouse myeloma cells stably transfected with human CD154, but not by the corresponding control cells, and this effect was specifically abrogated in the presence of an antiCD154 antibody.

Several other gene products, known to be up-regulated in SMC under proinflammatory conditions, were tested for CD40 inducibility. However, none of these was up-regulated by CD40 activation, revealing a rather specific pattern of CD40mediated gene expression in the SMC.

\subsection{CD40 induced MMP-3 expression is dependent on Src-like tyrosine kinase and p38 mitogen-activated protein kinase}

Mitogen-activated protein kinases (MAPKs) play an important role in regulating cell growth, differentiation, survival and death. To date, three mammalian MAPK pathways, the mitogen-activated ERK1/2 (Raf $\rightarrow$ MEK1/2 $\rightarrow$ ERK1/2), JNK (MEK kinase $1-4 \rightarrow$ MKK4/7 $\rightarrow$ JNK1-3) and p38 MAPK pathway (MAPKKK $\rightarrow$ MKK3/6 $\rightarrow$ p38 MAPK), activated by inflammatory cytokines and cellular stress, have been characterized in detail (Westermarck et al.,1999).

Using MMP-3 expression as a readout for CD40 signalling and specific protein kinase inhibitors directed against the aforementioned pathways, it could be demonstrated that p38 MAPK and c-src or a similar protein kinase are involved in CD40 signalling leading to the increased SMC expression of MMP-3. It has already been reported that CD40 activation affects the p38 MAPK pathway (Zhang et al., 2002). Several upstream regulators of p38 MAPK have been characterized in SMC, one of which is protein kinase C (PKC; Igarashi et al., 1999). However, inhibition of PKC with RO 31-8220 did not affect CD154-induced MMP-3 expression indicating that other signalling mechanisms are involved in the upstream regulation of p38 MAPK following CD40 activation. 
Another potential activator of p38 MAPK is p60/Src. The inhibitory effect of herbimycin A, a reasonably specific inhibitor of Src-like tyrosine kinase (Uehara et al., 1985), on CD154-induced MMP-3 expression suggested an involvement of Src-like tyrosine kinases in the upstream regulation of p38 MAPK activity in the SMC. Indeed, such a signal transduction pathway has already been documented in neutrophils and fibroblasts, respectively (Mocsai et al. 2000; Domeij et al., 2002).

The rho/ROCK pathway, playing a role in stretch-induced gene expression in SMC via p38 MAPK (Cattaruzza et al., 2001), was tested as a third potential mediator of CD40 signalling in MMP-3 expression. Interestingly, a specific inhibitor, Y27632, increased rather than decreased MMP-3 expression in response to CD154 stimulation, suggesting that the rho/ROCK pathway attenuates rather than contributes to CD40 signalling in the SMC.

One of the transcription factors activated by p38 MAPK and potentially responsible for MMP-3 expression is AP-1. An active consensus binding site for AP-1 has been characterized at position -70 in the $m m p-3$ gene promoter (Quinones et al., 1994). Moreover, activation of p38 MAPK was identified as an upstream event involved in the induction of AP-1 components and AP-1-controlled gene expression in SMC (Häcker et al., 1998). The other putative transcription factor involved in MMP-3 expression is $\mathrm{NF}-\kappa \mathrm{B}$. This transcription factor is required for cytokine up-regulation of MMP-3 in SMC (Bond et al., 2001). However, there is evidence that p38 MAPK activation alone is sufficient to induce MMP-3 expression in an AP-1-independent manner by stabilization of the mRNA in human fibroblasts (Reunanen et al., 2002).

The question which of the 2 mechanisms plays a role in CD40-induced MMP-3 expression in SMC was tested by inhibition of de novo RNA synthesis and application of decoy-oligonucleotides directed against $A P-1, N F-\kappa B$ and other transcription factors. Using the RNA II polymerase inhibitor, actinomycin D, prior to CD40 activation, resulted in a complete abolition of CD154-induced MMP-3 mRNA expression, indicating that the observed increase in MMP-3 mRNA abundance primarily is the result of an increased trancription. Assessing MMP-3 mRNA stability, again by employing actinomycin $D$, revealed a high half life of more than $12 \mathrm{~h}$. Thus, p38 MAPK-mediated stabilization of MMP-3 mRNA is unlikely to play a role in CD40mediated MMP-3 expression in the cultured SMC. 


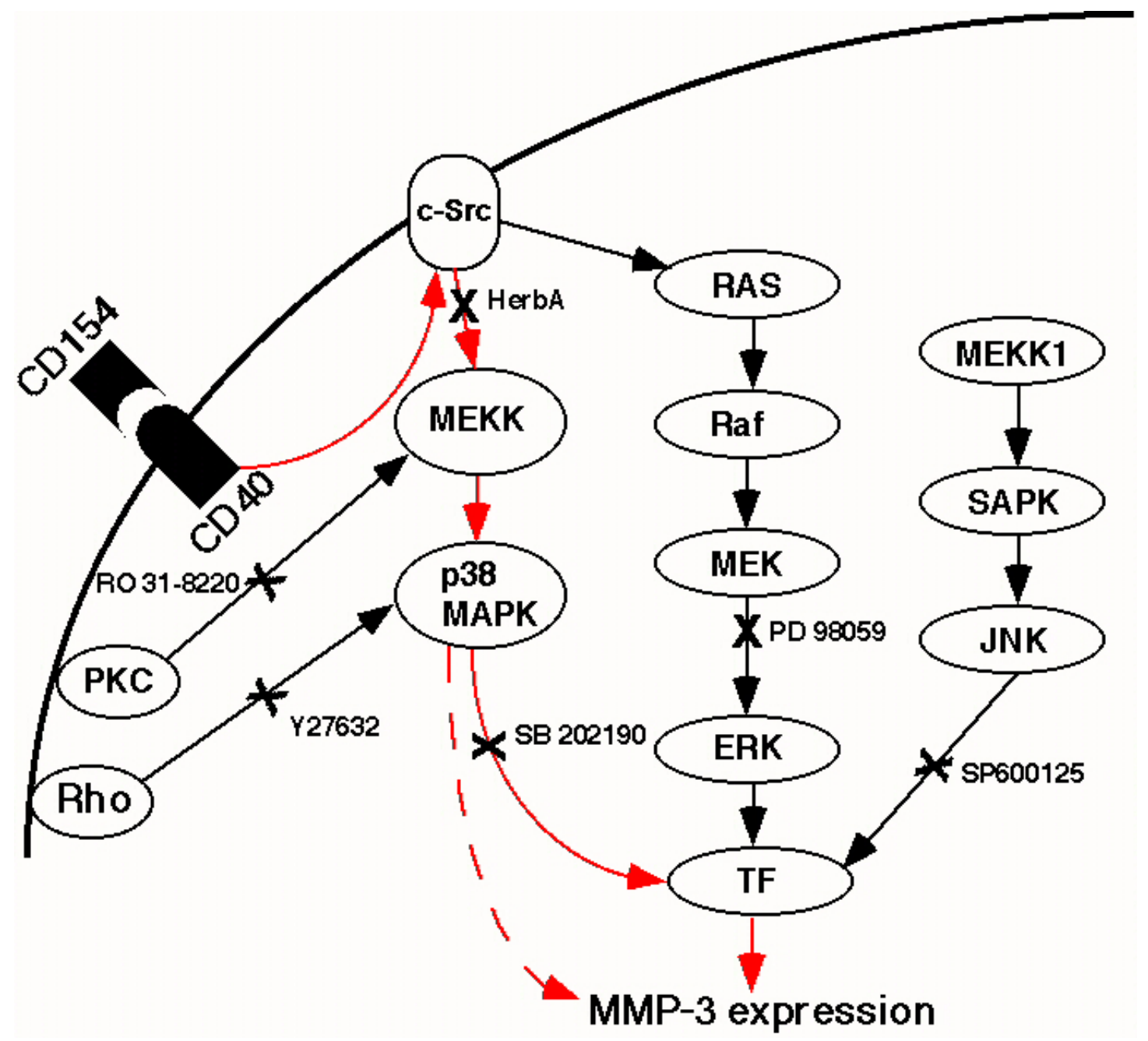

Figure 20. CD40 signalling pathways potentially leading to MMP-3 expression in SMC. The protein kinase pathways tested in this study are outlined. The only pathway that could be connected to CD40-induced MMP-3 expression is the pathway via c-Src and p38 MAPK (highlighted in red). The level of the interaction of inhibitors with the affected kinase pathways is marked by double-bars and the name of the respective inhibitor.

Furthermore, pre-treatment with cycloheximide prior to stimulation with CD154 did not block CD154 effects on MMP-3 mRNA expression, indicating that de novo synthesis of transcription factors is not essential for the up-regulation of MMP-3 expression. In an attempt to characterise latent transcription factors involved in MMP. 3 expression, decoy oligonucleotides against $\mathrm{AP}-1, \mathrm{NF}-\kappa \mathrm{B}$ and other related transcription factors were employed. Their lack of effect on MMP-3 expression, but not that of other gene products, excluded the involvement of these transcription factors in CD154-induced transcription of the mmp-3 gene. Thus, the exact 
mechanism of CD154-induced MMP-3 expression on this level still remains to be elucidated.

The putative upstream signalling mechanisms are summarized in Fig. 20.

\subsection{Characterization of CD40-mediated gene expression in SMC by DNA microarray analysis}

As stated before, CD40 activation in SMC results in an increase in MMP-3 and MCP1 expression. To gain a more detailed overview of the changes in CD40-induced gene expression in SMC, a DNA microarray approach was chosen. This technique offers a number of advantages over other potential screening methods for gene expression analysis. Besides giving the possibility of screening the expression of a large number of genes in parallel, another advantage is that relatively small amounts of RNA are required for this assay. The approach chosen here, i.e. performing three individual microarray experiments and applying rigorous selection criteria (i.e. counting only gene products with high quality signals that were up-regulated in response to CD154 in all three experiments) resulted in the characterization of only truly up-regulated gene products. This could be proven by subsequent RT-PCR analysis performed for 7 of gene products detected by DNA microarray to be CD154inducible. In addition, these gene products were selected on the basis of their relevance for the development of atherosclerosis (see below) and were confirmed to be up-regulated to a similar extent according to RT-PCR analysis as estimated by DNA microarray.

Thus, the list of differentially expressed gene products identified in this study is rather reliable (low abundance of false positive gene products). One disadvantage of the DNA microarray approach, on the other hand, is that several CD154-inducible gene products were not recognized due to the stringent selection criteria applied. According to the DNA microarray data, interaction of CD154-expressing myeloma cells with CD40-expressing SMC resulted in an pronounced pro-inflammatory response in the SMC. Most of the gene products up-regulated in CD40-activated SMC were pro-inflammatory molecules (chemokines and their receptors) including CCR7, GRO- $\beta$, GRO- $\gamma$, IL-15, IL-15 receptor $\alpha$, MCP-2, MIP-1 $\alpha$, MIP-3 $\alpha$, MMP-12 and ninjurin. Moreover, it would appear that expression of these gene products in human vascular SMC has been demonstrated for the first time in this study. 
Several of these pro-inflammatory molecules have similar biological actions, e.g. chemotactic activity, such as GRO $\beta$ and GRO $\gamma$ (Arenberg et al., 1997), RANTES (Dieu et al., 1998), fractalkine (Imai et al., 1997; Al-Aoukaty et al., 1998), MIP-1 $\alpha$ and MIP-3 $\alpha$ (Dieu et al., 1998), and GM-CSF (Dieu et al., 1998). They play a common role in leukocyte trafficking and dendritic cell maturation. One equally interesting CD154-induced ligand-receptor pair was expressed in the cultured SMC, i.e. IL-15 and IL-15 receptor $\alpha$. The parallel expression of the ligand and its receptor indicates a self-preserved pro-inflammatory process established by CD40 activation in SMC. IL-15 stimulates cytokine release in macrophages and lymphocytes (Mclnnes et al., 1997; Badolato et al., 1997) and acts as a chemokine for T-cells (Wilkinson et al., 1995). All of these findings, in correlation with the results of this study, imply that IL15 expression in CD40-activated SMC might not only contribute to local T-cell and monocyte activation and survival but also act on SMC in an autocrine manner. It is of particular interest that activation of T-cells by IL-15 is dependent on direct cell-to-cell contact but independent of specific antigenic stimulation (Mclnnes et al., 1997). IL-15 expression might thus be relevant for a non-specific chronic inflammation of the vessel wall including the non-specific activation of T-helper cells and SMC in atherosclerotic lesions. However, at this point, IL-15 effects on SMC are merely speculative, as expression of this cytokine and its receptor in SMC has not been described as yet.

Another interesting finding was that, unlike in endothelial cells (Lienenluke et al., 2000), activation of CD40 induces its own expression in SMC. This in turn could promote the interaction between CD154-expressing cells present in the vessel wall during inflammation and SMC, thereby fuelling the pro-inflammatory response.

\subsection{Functional significance of CD40 activation in SMC: activation of monocytes}

To analyse the effects of CD40 activation in SMC on monocytes, two different experimental approaches were chosen. Essentially they revealed that monocyte activation is dependent on the release of a humoral factor (chemokine or cytokine) from CD154-stimulated SMC rather than a cell-to-cell contact mediated by, e.g., adhesion molecules. This humoral factor or factors released by SMC in response to CD40 activation may be crucial for a full-blown macrophage-mediated vascular 
inflammation. Monocyte activation was confirmed by the detection of an increased expression of several marker genes in the THP-1 cells employed both on the mRNA and protein level. The obvious next question was which humoral factor is in fact responsible for monocyte activation? To this end, the list of differentially expressed genes revealed by DNA microarray was consulted first, essentially yielding GM-CSF, GRO- $\beta$, GRO- $\gamma$, MCP-2, MIP- $1 \alpha$ and MIP- $3 \alpha$ as potential candidates as well as IL-1 $\beta$ and IL-15. Previous findings that GM-CSF up-regulates, e.g., CD40 and IL-8 expression in human monocytes (Paquette et al., 1998; Baqui et al., 1999) prompted the investigation of this protein along with IL-15. By using neutralizing antibodies against these two proteins it could be confirmed that GM-CSF is, at least in part, responsible for the increase in gene expression in THP-1 cells exposed to the supernatant of CD154-stimulated SMC. GM-CSF contributes to monocyte survival and their differentiation to macrophages (Geissler et al., 1989), a process crucial for the development and propagation of the atherosclerotic process. Thus, blockade of CD40-mediated release of GM-CSF may have profound effect on this population of leukocytes during the progression of atherosclerosis.

\subsection{A model of the role of SMC CD40 in atherosclerosis}

Till now, most research based on the role of inflammation in atherosclerosis was pointed to the interaction of endothelial cells and leukocytes. Indeed, the endothelial cells of the vessel wall are the first barrier for circulating blood cells. Endothelial cell activation leads to the expression of adhesion molecules (e.g. E-selectin and VCAM1) and chemoattractants (MCP-1), which trigger leukocyte rolling, adhesion and migration into the vessel wall. However, once present within the vessel wall, leukocytes come into close contact with SMC, creating the potential for intercellular communication to occur. The results of this study indicate that CD40 is expressed under pro-inflammatory conditions on the surface of SMC. CD40 activation in SMC inevitably occurs through CD154/CD40 interaction when activated T-cells enter the vessel wall (Schonbeck et al., 1997). 


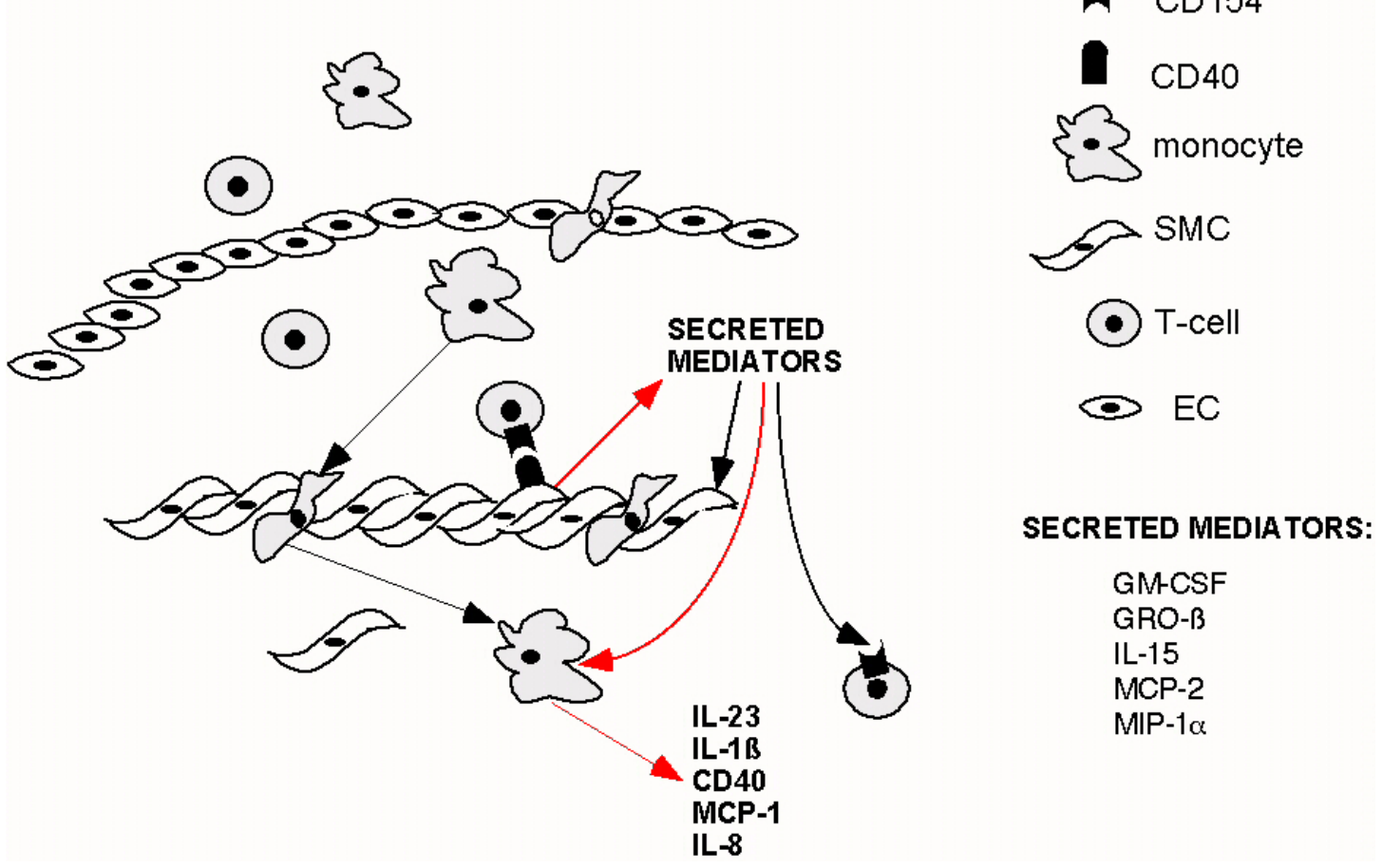

Figure 21. Effects of cell-to-cell interaction between CD40-activated SMC and monocytes. SMC under pro-inflamatory conditions express CD40. T-cells expressingCD154 interact with CD40-expressing SMC. As a result, SMC produce proinflammatory molecules that affect monocytes, T-cells and SMC present in inflamed vessel wall.

As shown here, the response of SMC to CD40 activation is the production of a variety of pro-inflammatory molecules, ranging from chemokines and their receptors to adhesion molecules. Pro-inflammatory molecules secreted from CD40-activated SMC can principally affect 3 different types of cells (Fig. 21). First, molecules like GM-CSF or MCP-1 act as chemoattractants for monocytes and provoke their maturation. Secondly, by secreted mediators from CD40-activated SMC such as, e.g., IL-15 are responsible for T-cell maturation. This cytokine also induces expression of CD154 on activated T-cells, suggesting a positive feed-back loop between activated T-cells and SMC. Thirdly, CD40 activation induces its own expression as well as the expression of several ligand-receptor systems (e.g. IL15/IL-15 receptor or CCR7 and several ligands) in SMC. CD40 activation in SMC, although strongly activated already by other cytokines such as TNF $\alpha$ plus IFN $\gamma$ does not seem to be just another activated receptor-ligand system but leads, as could be shown herein for the first time, to the expression of gene products that truly promote the activation of monocytes/macrophages, T-cells and potentially also SMC themselves. Thus, one likely consequence of these changes in gene expression in 
the SMC might be the initiation and maintenance of a vicious cycle in which the 3 cell types interact with each other to fuel the inflammatory response. Continuous attraction and activation of inflammatory cells, as well as propagation of a predominant Th1-mediated immune response, might figure among the most prominent CD154-mediated processes contributing to the progression of atherosclerotic lesions toward the vulnerable, rupture-prone plaque. In this context, elucidating the signalling pathway activated following CD40 stimulation in SMC appears to be a therapeutically relevant goal. 


\section{Summary}

In the pathogenesis of atherosclerosis, circulating leukocytes adhere to endothelial cells, migrate through them and enter the vessel wall. CD40, a member of the tumor necrosis factor receptor family, that is expressed by both leukocytes and endothelial cells plays an important role in this process. Upon their emigration into the vessel wall leukocytes come into contact with the vascular smooth muscle cells (SMC). These cells also play a major role in the development and progression of atherosclerosis and express CD40 under pro-inflammatory conditions. The aim of the present study was to answer the question which role CD40 expression in SMC might play in the context of atherosclerosis. To address this complex question, four different experimental approaches were taken: (i) analysis of CD40 expression itself in human cultured SMC, (ii) analysis of CD154-induced gene expression in these cells, as well as (iii) the signal transduction pathways involved therein, and (iv) investigating possible functional consequences of these changes in gene expression. A first result achieved was that under pro-inflammatory conditions, CD40 expression is markedly up-regulated in human cultured SMC. Moreover, activation of CD40 in these cells resulted in the differential expression of 36 genes, as judged by DNA microarray and confirmed by RT-PCR analysis. Most of these gene products were up-regulated and comprised pro-inflammatory molecules, namely chemokines and their receptors, cytokines and their receptors, and adhesion molecules. The expression of these gene products in human SMC could be demonstrated for the first time.

To elucidate the signalling pathways linking CD40-CD154 interaction to gene expression in the SMC, CD40-induced matrix metalloproteinase-3 (MMP-3) expression was chosen as a readout. By using different pharmacological inhibitors, it was demonstrated that the tyrosine kinase c-Src and the mitogen-activated protein kinase p38 are involved in CD40 signalling to the nucleus in these cells. Moreover, MMP-3 expression was verified to be up-regulated on the level of transcription, although the transcription factor(s) responsible therefor could not be identified as yet. By using two different experimental approaches, a SMC-monocyte interaction assay and analysing changes in gene expression in these cells upon exposure to the conditioned medium of CD154-stimulated SMC, it was further shown that monocyte activation is mediated by a humoral factor rather than a cell-to-cell contact. Further 
investigations, employing neutralizing antibodies, revealed that granulocytemacrophage colony-stimulating factor is a likely candidate for the monocyteactivating humoral factor.

Collectively, these findings suggest that vascular SMC like endothelial cells contribute to the maintenance of an inflammatory response in the vessel wall as, e.g., in atherosclerosis when stimulated via the CD40/CD154 receptor/ligand dyad. Elucidating the transcriptional mechanism by which CD40 activation in these cells is translated into the release of pro-inflammatory mediators represents a valuable therapeutic goal in this context. 


\section{References}

Aagaard-Tillery KM, Jelinek DF. (1996). Phosphatidylinositol 3-kinase activation in normal human B lymphocytes. J Immunol 156: 4543-4554.

Al-Aoukaty A, Rolstad B, Giaid A, Maghazachi AA. (1998). MIP-3alpha, MIP-3beta and fractalkine induce the locomotion and the mobilization of intracellular calcium, and activate the heterotrimeric $\mathrm{G}$ proteins in human natural killer cells. Immunology 95: 618-624.

Alderson MR, Armitage RJ, Tough TW, Strockbine L, Fanslow WC, Spriggs MK. (1993). CD40 expression by human monocytes: regulation by cytokines and activation of monocytes by the ligand for CD40. J Exp Med 178: 669-674.

Allen RC, Armitage RJ, Conley ME, Rosenblatt H, Jenkins NA, Copeland NG, Bedell MA, Edelhoff S, Disteche CM, Simoneaux DK, et al. (1993). CD40 ligand gene defects responsible for X-linked hyper-IgM syndrome. Science 259: 990-993.

Arenberg DA., Polverini PJ, Kunkel SL, Shanafelt A, Hesselgesser J, Horuk R, Strieter RM. (1997). The role of CXC chemokines in the regulation of angiogenesis in non-small cell lung cancer. J Leukocyte Biol 62: 554-562.

Badolato R, Ponzi AN, Millesimo M, Notarangelo LD, Musso T. (1997). Interleukin-15 (IL-15) induces IL-8 and monocyte chemotactic protein 1 production in human monocytes. Blood 90: 2804-2809.

Baqui AA, Meiller TF, Falkler WA. (1999). Enhanced interleukin-8 production in THP1 human monocytic cells by lipopolysaccharide from oral microorganisms and granulocyte-macrophage colony-stimulating factor. Oral Microbiol Immunol 14: 275280.

Bond M, Chase AJ, Baker AH, Newby AC. (2001). Inhibition of transcription factor NF-kappaB reduces matrix metalloproteinase- $-1,-3$ and -9 production by vascular smooth muscle cells. Cardiovasc Res 50: 556-565.

Boring L, Gosling J, Cleary M, Charo IF. (1998). Decreased lesion formation in CCR2 -/- mice reveals a role for chemokines in the initiation of atherosclerosis. Nature 394: 894-897. 
Brady K, Fitzgerald S, Moynagh PN. (2000). Tumour-necrosis-factor-receptorassociated factor 6, NF-kappaB-inducing kinase and IkappaB kinases mediate IgE isotype switching in response to CD40. Biochem $\mathrm{J} 350: 735-740$.

Campbell GR, Campbell JH. (1985). Smooth muscle phenotypic changes in arterial wall homeostasis: implications for the pathogenesis of atherosclerosis. Exp Mol Pathol 42: 139-162.

Cattaruzza M, Eberhardt I, Hecker M. (2001). Mechanosensitive Transcription Factors Involved in Endothelin B Receptor Expression. J Biol Chem 276: 3699937003.

Darnell JE Jr, Kerr IM, Stark GR. (1994). Jak-STAT pathways and transcriptional activation in response to IFNs and other extracellular signaling proteins. Science 264: 1415-1421.

Dieu MC, Vanbervliet B, Vicari A, Bridon JM, Oldham E, Ait-Yahia S, Briere F, Zlotnik A, Lebecque S, Caux C. (1998). Selective recruitment of immature and mature dendritic cells by distinct chemokines expressed in different anatomic sites. J Exp Med 188: 373-386.

Domeij H, Yucel-Lindberg T, Modeer T. (2002). Signal pathways involved in the production of MMP-1 and MMP-3 in human gingival fibroblasts. Eur J Oral Sci 110: 302-306.

Dubois S, Magrangeas F, Lehours P, Raher S, Bernard J, Boisteau O, Leroy S, Minvielle S, Godard A, Jacques Y. (1999). Natural splicing of exon 2 of human interleukin-15 receptor alpha-chain mRNA results in a shortened form with a distinct pattern of expression. J Biol Chem 274: 26978-26984.

Durandy A, Schiff C, Bonnefoy JY, Forveille M, Rousset F, Mazzei G, Milili M, Fischer A. (1993). Induction by anti-CD40 antibody or soluble CD40 ligand and cytokines of $\lg G$, IgA and $\lg E$ production by $B$ cells from patients with $X$-linked hyper IgM syndrome. Eur J Immunol 23: 2294-2299.

Emeson EE, Robertson AL Jr. (1988). T lymphocytes in aortic and coronary intimas. Their potential role in atherogenesis. Am J Pathol 130: 369-376.

Eriksson EE, Werr J, Guo Y, Thoren P, Lindbom L. (2000). Direct observations in vivo on the role of endothelial selectins and alpha(4) integrin in cytokine-induced leukocyte-endothelium interactions in the mouse aorta. Circ Res 86: 526-533. 
Fuster, V. Lewis A. Conner Memorial Lecture. (1994). Mechanisms leading to myocardial infarction: Insights from studies of vascular biology. Circulation 90: 21262146.

Galis ZS, Muszynski M, Sukhova GK, Simon-Morrissey E, Unemori EN, Lark MW, Amento E, Libby P. (1994). Cytokine-stimulated human vascular smooth muscle cells synthesize a complement of enzymes required for extracellular matrix digestion. Circ Res 75: 181-189.

Geissler K, Harrington M, Srivastava C, Leemhuis T, Tricot G, Broxmeyer HE. (1989). Effects of recombinant human colony stimulating factors (CSF) (granulocytemacrophage CSF, granulocyte CSF, and CSF-1) on human monocyte/macrophage differentiation. J Immunol 143: 140-146.

Grewal IS, Flavell RA. (1998). CD40 and CD154 in cell-mediated immunity. Annu Rev Immunol 16: 111-135.

Häcker, H., Mischak, H., Miethke, T., Liptay, S., Schmid, R., Sparwasser, T., Heeg, K., Lipford, G. B., and Wagner, H. (1998). CpG-DNA-specific activation of antigenpresenting cells requires stress kinase activity and is preceded by non-specific endocytosis and endosomal maturation. EMBO J 17: 6230-6240.

Henn V, Slupsky JR, Grafe M, Anagnostopoulos I, Forster R, Muller-Berghaus G, Kroczek RA. (1998). CD40 ligand on activated platelets triggers an inflammatory reaction of endothelial cells. Nature 391: 591-594.

Horton DB, Libby P, Schonbeck U. (2001). Ligation of CD40 on vascular smooth muscle cells mediates loss of interstitial collagen via matrix metalloproteinase activity. Ann N Y Acad Sci 947: 329-336.

Igarashi M, Wakasaki H, Takahara N, Ishii H, Jiang ZY, Yamauchi T, Kuboki K, Meier M, Rhodes CJ, King GL. (1999). Glucose or diabetes activates p38 mitogen-activated protein kinase via different pathways. J Clin Invest 103: 185-195.

Imai T, Hieshima K, Haskell C, Baba M, Nagira M, Nishimura M, Kakizaki M, Takagi S, Nomiyama H, Schall TJ, Yoshie O. (1997). Identification and molecular characterization of fractalkine receptor CX3CR1, which mediates both leukocyte migration and adhesion. Cell 91: 521-530. 
Ishida TK, Tojo T, Aoki T, Kobayashi N, Ohishi T, Watanabe T, Yamamoto T, Inoue J. (1996). TRAF5, a novel tumor necrosis factor receptor-associated factor family protein, mediates CD40 signalling. Proc Natl Acad Sci 93: 9437-9442.

Karmann K, Hughes CC, Schechner J, Fanslow WC, Pober JS. (1995). CD40 on human endothelial cells: inducibility by cytokines and functional regulation of adhesion molecule expression. Proc Natl Acad Sci U S A 92: 4342-4346.

Karmann K, Min W, Fanslow WC, Pober JS. (1996). Activation and homologous desensitization of human endothelial cells by CD40 ligand, tumor necrosis factor, and interleukin 1. J Exp Med 184: 173-182.

Karras JG, Wang Z, Huo L, Frank DA, Rothstein TL. (1997). Induction of STAT protein signaling through the CD40 receptor in B lymphocytes: distinct STAT activation following surface Ig and CD40 receptor engagement. J Immunol 159: 4350-4355.

Krzesz R, Wagner AH, Cattaruzza M, Hecker M. (1999). Cytokine-inducible CD40 gene expression in vascular smooth muscle cells is mediated by nuclear factor kappaB and signal transducer and activation of transcription-1. FEBS Lett 453: 191196.

Li H, Cybulsky MI, Gimbrone MA Jr, Libby P. (1993). An atherogenic diet rapidly induces VCAM-1, a cytokine regulatable mononuclear leukocyteadhesion molecule, in rabbit endothelium. Arterioscler Thromb 13: 197-204.

Li S, Fan YS, Chow LH, Van Den Diepstraten C, van Der Veer E, Sims SM, Pickering JG. (2001). Innate diversity of adult human arterial smooth muscle cells: cloning of distinct subtypes from the internal thoracic artery. Circ Res 89: 517-525.

Libby P, Galis ZS. (1995). Cytokines regulate genes involved in atherogenesis. Ann N Y Acad Sci 748: 158-170.

Libby P, Aikawa M. (2002). Stabilization of atherosclerotic plaques: new mechanisms and clinical targets. Nat Med 8: 1257-1262.

Lienenluke B, Germann T, Kroczek RA, Hecker M. (2000). CD154 stimulation of interleukin-12 synthesis in human endothelial cells. Eur J Immunol 30: 2864-2870. 
Ludewig B, Henn V, Schroder JM, Graf D, Kroczek RA. (1996). Induction, regulation, and function of soluble TRAP (CD40 ligand) during interaction of primary CD4+ CD45RA+ T cells with dendritic cells. Eur J Immunol 26: 3137-3143.

Mach F, Schonbeck U, Sukhova GK, Bourcier T, Bonnefoy JY, Pober JS, Libby P. (1997). Functional CD40 ligand is expressed on human vascular endothelial cells, smooth muscle cells, and macrophages: Implication for CD40-CD40 ligand signalling in atherosclerosis. Proc. Natl. Acad. Sci. USA 94: 1931-1936.

Mach F, Schonbeck U, Sukhova GK, Atkinson E, Libby P. (1998). Reduction of atherosclerosis in mice by inhibition of CD40 signalling. Nature 394: 200-203.

McInnes IB, Leung BP, Sturrock RD, Field M, Liew FY. (1997). Interleukin-15 mediates $\mathrm{T}$ cell-dependent regulation of tumor necrosis factor-alpha production in rheumatoid arthritis. Nat Med 3: 189-195.

Mocsai A, Jakus Z, Vantus T, Berton G, Lowell CA, Ligeti E. (2000). Kinase pathways in chemoattractant-induced degranulation of neutrophils: the role of p38 mitogenactivated protein kinase activated by Src family kinases. J Immunol 164: 4321-4331.

Mosse PR, Campbell GR, Wang ZL, Campbell JH. (1985). Smooth muscle phenotypic expression in human carotid arteries. I. Comparison of cells from diffuse intimal thickenings adjacent to atheromatous plaques with those of the media. Lab Invest 53: 556-562.

Paquette RL, Hsu NC, Kiertscher SM, Park AN, Tran L, Roth MD, Glaspy JA. (1998). Interferon-a and granulocyte-macrophage colony-stimulating factor differentiate peripheral blood monocytes into potent antigen-presenting cells. J Leukoc Biol 64: 358-367.

Paulie S, Koho H, Ben-Aissa H, Hansson Y, Lundblad ML, Perlmann P. (1984). Monoclonal antibodies to antigens associated with transitional cell carcinoma of the human urinary bladder. II. Identification of the cellular target structures by immunoprecipitation and SDS-PAGE analysis. Cancer Immunol Immunother 17: 173179.

Peitsch MC, Jongeneel CV. (1993). A 3-D model for the CD40 ligand predicts that it is a compact trimer similar to the tumor necrosis factors. Int Immunol 5: 233-238.

Pullen SS, Labadia ME, Ingraham RH, McWhirter SM, Everdeen DS, Alber T, Crute JJ, Kehry MR. (1999). High-affinity interactions of tumor necrosis factor receptor- 
associated factors (TRAFs) and CD40 require TRAF trimerization and CD40 multimerization. Biochemistry 38: 10168-10177.

Quinones S, Buttice G, Kurkinen M. (1994). Promoter elements in the transcriptional activation of the human stromelysin-1 gene by the inflammatory cytokine, interleukin 1. Biochem J 302: 471-477.

Reunanen N, Li SP, Ahonen M, Foschi M, Han J, Kahari VM. (2002). Activation of p38 alpha MAPK enhances collagenase-1 (matrix metalloproteinase (MMP)-1) and stromelysin-1 (MMP-3) expression by mRNA stabilization. J Biol Chem 277: 3236032368.

Ross, R. and Glomset, J.A. (1973). Atherosclerosis and the arterial smooth muscle cell: Proliferation of smooth muscle is a key event in the genesis of the lesions of atherosclerosis. Science 180: 1332-1339.

Ross R. (1993). The pathogenesis of atherosclerosis: a perspective for the 1990s. Nature 362: 801-809.

Ross R. (1999). Atherosclerosis--an inflammatory disease. N Engl J Med 340: 115126.

Russell ME, Adams DH, Wyner LR, Yamashita Y, Halnon NJ, Karnovsky MJ. (1993). Early and persistent induction of monocyte chemoattractant protein 1 in rat cardiac allografts. Proc Natl Acad Sci U S A 90: 6086-6090.

Schonbeck U, Mach F, Bonnefoy JY, Loppnow H, Flad HD, Libby P. (1997). Ligation of CD40 activates interleukin 1beta-converting enzyme (caspase-1) activity in vascular smooth muscle and endothelial cells and promotes elaboration of active interleukin 1beta. J Biol Chem 272: 19569-19574.

Schonbeck U, Mach F, Sukhova GK, Herman M, Graber P, Kehry MR, Libby P. (2000). CD40 ligation induces tissue factor expression in human vascular smooth muscle cells. Am J Pathol 156: 7-14.

Schonbeck U, Libby P. (2001). The CD40/CD154 receptor/ligand dyad. Cell Mol Life Sci 58: 4-43.

Schwabe RF, Schnabl B, Kweon YO, Brenner DA. (2001). CD40 activates NF-kappa $\mathrm{B}$ and c-Jun $\mathrm{N}$-terminal kinase and enhances chemokine secretion on activated human hepatic stellate cells. J Immunol 166: 6812-6819. 
Schwartz SM., de Blois D, O'Brien ERM. (1995). The intima. Soil for atherosclerosis and restenosis. Circ. Res 77: 445-465.

Shepherd J. (1995). The West of Scotland Coronary Prevention Study: a trial of cholesterol reduction in Scottish men. Am J Cardiol 76: 113C-117C.

Smith JD, Trogan E, Ginsberg M, et al. (1995). Decreased atherosclerosis in mice deficient in both macrophage colony-stimulating factor (op) and apolipoprotein $\mathrm{E}$. Proc Natl Acad Sci U S A 92: 8264-8268.

Springer TA. (1994). Traffic signals for lymphocyte recirculation and leukocyte emigration: the multistep paradigm. Cell 76: 301-314.

Stamenkovic I, Clark EA, Seed B. (1989). A B-lymphocyte activation molecule related to the nerve growth factor receptor and induced by cytokines in carcinomas. EMBO J 8: 1403-1410.

Tan J, Town T, Mullan M. (2000). CD45 inhibits CD40L-induced microglial activation via negative regulation of the Src/p44/42 MAPK pathway. J Biol Chem 275: 3722437231 .

Tsuchiya S, Yamabe M, Yamaguchi Y, Kobayashi Y, Konno T, Tada K. (1980). Establishment and characterization of a human acute monocytic leukemia cell line (THP-1). Int J Cancer 26: 171-176.

Uckun FM, Schieven GL, Dibirdik I, Chandan-Langlie M, Tuel-Ahlgren L, Ledbetter JA. (1991). Stimulation of protein tyrosine phosphorylation, phosphoinositide turnover, and multiple previously unidentified serine/threonine-specific protein kinases by the Pan-B-cell receptor CD40/Bp50 at discrete developmental stages of human B-cell ontogeny. J Biol Chem 266: 17478-17485.

Uehara Y, Hori M, Takeuchi T, Umezawa H. (1985). Screening of agents which convert 'transformed morphology' of Rous sarcoma virus-infected rat kidney cells to 'normal morphology': identification of an active agent as herbimycin and its inhibition of intracellular src kinase. Jpn J Cancer Res 76: 672-675.

Wagner AH, Gebauer M, Pollok-Kopp B, Hecker M. (2002). Cytokine-inducible CD40 expression in human endothelial cells is mediated by interferon regulatory factor- 1 . Blood 99: 520-525. 
Westermarck J, Holmstrom T, Ahonen M, Eriksson JE, Kahari VM. (1998). Enhancement of fibroblast collagenase-1 (MMP-1) gene expression by tumor promoter okadaic acid is mediated by stress-activated protein kinases Jun $\mathrm{N}$-terminal kinase and p38. Matrix Biol 17: 547-557.

Wilkinson PC, Liew FY. (1995). Chemoattraction of human blood T lymphocytes by interleukin-15. J Exp Med 181: 1255-1259.

Wykes M, Poudrier J, Lindstedt R, Gray D. (1998). Regulation of cytoplasmic, surface and soluble forms of CD40 ligand in mouse B cells. Eur J Immunol 28: 548-559.

Yellin MJ, Brett J, Baum D, Matsushima A, Szabolcs M, Stern D, Chess L. (1995). Functional interactions of $T$ cells with endothelial cells: the role of CD40L-CD40mediated signals. J Exp Med 182: 1857-1864.

Zhang K, Zhang L, Zhu D, Bae D, Nel A, Saxon A. (2002). CD40-mediated p38 mitogen-activated protein kinase activation is required for immunoglobulin class switch recombination to IgE. J Allergy Clin Immunol 110: 421-428. 


\section{Acknowledgments}

First of all I would like to express my deep and sincere gratitude to my supervisor Prof. Dr. M. Hecker for giving me the opportunity to prepare this thesis in the fascinating field of cardiovascular physiology. I greatly appreciate his scientific supervision during my work, encouragement and help, his patience and valuable suggestions for improvement of the thesis manuscript.

I sincerely thank Prof. Dr. R. Hardeland, who supervised my thesis and Prof. Dr. W. Engel for being my co-referee. I also extend my sincere thanks to Prof. Dr. D. Gradmann for accepting to be my examiner.

My grateful thanks goes to Dr. M. Cattaruzza for his excellent collaboration during all four years, for patiently attendance to any questions and reviewing the thesis manuscript, to Dr. R. Krzesz for many useful suggestions and for helping me out with all the computers, to Dr. Andreas Wagner for all his advices concerning my work.

I am very grateful to all technical assistants, especially to Annette Bennemann for her assistance in cell culture and Renate Dohrmann for a nice working atmosphere.

I would like to thank all other people at the department, especially Dr. Dincheng Gao for his help and encouragement, Bettina Bolli for her helpfulness during these years and Nicole Nogoy for being an inspiring colleague.

Many thanks to all my friends in Göttingen, especially Elitsa for support and a nice friendship, and Čeda for the support he has given me.

My warmest thanks to my family for their support and enthusiasm over the years, and for always believing in me. 


\section{CURRICULUM VITAE}

\section{$\underline{\text { Name }}$}

Milica Stojakovic

\section{Personal data}

Born: $19^{\text {th }}$ October 1971 in Belgrade, Republic of Serbia, Yugoslavia

\section{Citizenship}

Serbian

\section{Education}

1978-1986; Primary school, Belgrade

1986-1990; Secondary school, Belgrade

1990-1998; Study of Biology at the University of Belgrade, Faculty of Biology, Department of Molecular Biology and Physiology, Group of Experimental

Biomedicine; finished 34 courses in science and 4 in humanities 1997-1998; Diploma work entitled „Mosaic cariotype in a patient with Turner's syndrome diagnosed by cytogenetic and molecular techniques" carried out in the Hospital for Mother and Child Health, Belgrade 2000-2003; Postgraduate study of Biology at the University of Göttingen; associate member of the GK 335

\section{Research} 1998-1999; Research Assistant in the Laboratory for Radiobiology and Molecular Genetics, Institute of Nuclear Sciences, Vinca, Belgrade 2000-2003; working as a PhD student in the Department of Cardiovascular Physiology, University of Göttingen; preparation of the present PhD thesis "Role of the CD40 receptor/CD154 ligand dyad in the control of smooth muscle cell phenotype“. 